\title{
"Trilce" y los Límites de la Poesía
}

\author{
Por ANDRÉ COYNÉ
}

\section{I.- LA EPOCA DE TRILCE}

Cuatro años separan la publicación de Trilce de la de Los Heraldos Negros : son años importantes no sólo para Vallejo, sino también para la evolución posterior de la literatura peruana.

González Prada muere súbitamente el 22 de Julio de 1918 y Valdelomar es víctima de un accidente fatal el 2 de Noviembre de 1918. Mariátegui, que se dió primero a conocer como poeta modernista en Colónida, empieza a orientarse hacia actividades sociales y políticas $\mathrm{y}$. después de fundar sucesivamente Nuestra Epoca y La Razón, abandona en 1920 el Perú, adonde yolverá en 1923, convertido a los nuevos credos socialistas. Paraielamente, en las principales ciudades del país, la agitación universitaria, conectada con ciertas aspiraciones populares, adquiere proporciones nunca vistas.

Matriculado en la Facultad de Letras de la Universidad de San Mar$\cos _{\gamma_{2}}$ en el año 1919, pueda ser que Vallejo se adhiriera al movimiento reinvindicatorio. Lo cierto es que ya está pensando en viajar a Europa para no volver : "Sólo puedo vivir bien en mi terruño (se trata de Santiago de Chuco) o en París", confiesa un día a Angela Ramos, asociando en forma privilegiada el lugar donde nació y aquel donde había finalmente de morir.

Entre tanto, la vida cotidiana, con sus exigencias más triviales, requiere al poeta y lo limita: Vallejo se reincorpora en el oficio de "preceptor" que ya practicara en Trujillo. La crítica oficial no ha recibido muy bien su primer libro: en un periódico del tiempo han desafiado al artista a que explique sus poemas, y entre otros, el llamado Deshojación Sagrada, que es sin embargo uno de los menos originales de Los Heraldos Negros. En el mismo Colegio de Guadalupe, en el cual Va- 
llejo es maestro de primaria, Alberto Ureta, poeta entonces de gran fama y profesor de literatura en la sección de media, se burla del loco provinciano que escribe extravagancias, con la intención evidente de no darse a comprender.

El autor de Escalas Melografiadas nos ha dejado, en varias páginas del libro, referencias a su existencia de aquellos días en la capital peruana (1) : "Oh mi bohemia de entonces..." exclama por ejemplo en Cera. Algunos testimonios de contemporáneos pueden precisar la atmósfera en medio de la cual se desarrollaba la existencia aquí aludida; pero nada entre los informes recogidos se relaciona con la actividad propiamente creadora de Vallejo, en los años en que precisamente maduraban los poemas de Trilce.

Desaparecidos Valdelomar y González Prada, nadie los reemplaza como maestros o inspiradores. La librería "La Aurora Literaria" era uno de los pocos sitios que acogía a los escritores y artistas independientes; quienes vieron ahí a Vallejo han conservado una impresión física fuerte, viva y siempre concordante: "con sus ojos profundos, su melena negra y lacia, sus arrugas que le trabajaban el rostro y su gran frente", el poeta se distinguía por la tristeza infinita de la mirada, y al mismo tiempo la excesiva dulzura, la discreción, la corrección nunca alteradas por las contingencias de la "bohemia". Bohemia que, además, los tantos relatos de "borracheras", que los sobrevivientes nos presentan, falsifican, queriendo reducir algo esencial a lo anecdótico y externo de los hechos No podemos nosotros separar todas las incursiones nocturnas a los cafés $\mathrm{y}$ a los fumaderos de opio del barrio chino o del centro de Lima, del contexto mental que, en el caso de Vcrllej", las habilitaba: en un ambiente de pobreza material, la presencia del autor de Trilce bastaba para determinar una corriente de calor humano que involucraba al más humilde y descubría las reservas inmensas de bondad que el pudor ordinario del poeta ocultaba. No hay nin. guna afectación literaria en la actitud de un hombre extremadamente sencillo, pues al contrario, el silencio que el escritor observaba sobre su obra muy raras veces cedía a las instancias de los amigos o compañeros, que trataban de penetrar en su misterio.

La madre de Vallejo ha muerto en el mes de Agosto de 1918 : el sentimiento de "orfandad", que aparecía ya en Los Heraldos Negros,

(1) En Tralce $L X X$, encontraremos igualmente una referencia al balneario de Barranco: "Que interinos Barrancos no hay en los esenciales cementerisa" 
dominará muchos poemas de Trilce, confiriendo a la poesía vallejana, después de aquella fecha, un tono cada vez más doloroso y para siempre desamparado. El hijo estaba muy lejos para enterarse a tiempo de la muerte de quien lo despertara en otros tiempos "con cantora y linda cólera materna", pero al recibir la noticia irreparable, el huérfano sintió crecer nuevamente el deseo de visitar, la tierra donde transcurriera su niñez. Por eso, cuando, en 1920, el Colegio de Guadalupe disminuyó el número de clases de primaria y despidió a buena parte del personal, entre otros a Vallejo, éste aprovecho inmediatamente su libertad recobrada para emprender el viaje del norte y de la sierra. Parece que la resolución de ir a Francia fué anterior a dicho viaje que, en la mente del poeta, constituía, al mismo tiempo que una peregrinación, una despedida.

Sucesos inesperados iban a retrasar la partida proyectada a Euro$\mathrm{pa}$, pero de todas maneras sería esta la última vez que Vallejo cruzaría las tierras altas de los Andes que, antes de embarcarse para siempre, evocaría en Fabla Salvaje, relato de un idilio trágico donde dos jóvenes campesinos se enfrentan a los paisajes "preñados de electricidad y de hórridos presagios" familiares al campesino andino. La técnica del cuento no nos ofrecerá nada particularmente nuevo, pero la atmósfera en la cual está situado nos revelará la persistencia de impresiones telúricas primitivas (Cf. más tarde : Telúrica y Magnética en Poemas Humanos) de las que (surgen ta angustia Simprecisa y el afán de ternura redentorg, ya sensibles a lo dargo de Los Heraldos Negros. Semejante experiencia que rápidamente adquiere en los poemas un valor universal (2) descubre en la narración en prosa todo lo que la vincula con el cuadro propio de la niñez. El hombre tiene "una mirada... vegetal y lapidea expresión"; en su "viril dulcedumbre andina" recibe de golpe los presagios que le dirige una naturaleza habitada por misteriosas potencias elementales, y desde entonces, "sacudido de un escalofrío de inmensa orfandad", el ser, bueno, fuerte y alegre, se ve perseguido por un intruso que le roba su cara en el espejo y cuya mano lo empuja desde atrás hasta precipitarlo en el abismo - un intruso sin forma ni identidad, que únicamente tiene parecido con "ese oscuro", mencionado en el poema La Cena Miserable.

Antes de llegar a la ciudad natal, en Julio de 1920, Valiejo pasa por Huamachuco y participa en una manifestación culturai organizada por el Colegio San Nicolás, en donde había hecho sus estudios secunda-

(2) Véase el estudio sobre Los Heraldos Negres. 
rios. De los incidentes que aquel día ocurrieron, recordaremos solamente la afirmación pública, por parte del poeta, de una fe orguilosa en su obra escrita y por escribir, obra que, según palabras propias, lo haría algún día más famoso que el mismo Rubén Darío.

Con el viaje a Santiago y la llegada del poeta, "jadeante de lacerada temura" (Los Caynas), a la vieja casona, silenciosa desde que la madre ha dejado de esperar al pródigo, están relacionados los poemas XXIII, LXI y LXV de Trilce (véase también Tr. LVIII) (3). Lo que ocurrió en los días siguientes no será nunca completamente esclarecido: durante muchos años los comentaristas han aludido al encarcelamiento de Vallejo como a la culminación de odios antiguos que habrían provocado acusaciones falsas y malevolentes, sin el menor fundamento en la realidad. Como he podido comprobarlo, viajando a Trujillo y a Santiago de Chuco, para oír testimonios contradictorios y consultar por primera vez el expediente del proceso en el cual Vallejo se encontró complicado, el conocimiento de los hechos, reales, que provocaron la prisión del poeta no nos permite concluir definitivamente sobre una controversia, por lo demás inútil, pues lo único importante para nosotros, treinta años después, son las consecuencias en la vida del hombre y en la creación del artista que los hechos mismos han originado. Vallejo adquirió en la cárcel una nueva experiencia de la condición misera. ble del hombre y el desomparo de un solo ser, que las leyes separan y señalan a la falsa concienciá colectiva, basta para condenar la justicia que lo condena a sentirse un ilota entre los hombres.

En mi artículo de Mar del $: u r-$ No 8 - he intentado desembrollar en lo posible los acontecinientiss do'orosos de Santiago de Chuco y no recordaré ahora sino lo necesario para la comprensión general de lo que sigue. Es el último día de las fiestas patronales de Santiago, $1^{\circ}$ de Agosto de 1920, cuando ocurren crctos abusivos y sangrientos, que se explican por la ebriedad y la excitación de una semana de festividades, y que son inmediatamente explotados por personas de intención dudosa, hasta culminar, horas más tarde, en el incendio del establecimiento comercial más importante de la ciudad. Vallejo estaba presente cuando sucedieron tales hechos $\mathrm{y}$, a pesar de que su participación nunca fué probada en el curso del proceso subsecuente, en la atmósfera propia de la capital provincial, desde siempre dividida entre dos bandos rivales bastaba que el poeta y su familia estuviesen vinculados con uno de los partidos para que las sospechas recayeran sobre él. En cuan-

(3) Y asimismo el cuento de Escalas Melografiadas titulado Más allá de la vida $y$ de la muerie, que nos of rece una transposición fantástica del suceso. 
to al encarcelamiento, fue consecuencia de una infeliz casualidad, pues, mientras tanto, los demás acusados, algunos de ellos, si, con cargos precisos, seguían viviendo en una clandestinidad relativamente fácil, dadas las condiciones de la existencia provincial de entonces.

Vallejo ingresó a la córcel de Trujillo el 6 de Noviembre de 1920; fue puesto en libertad condicional el 26 de febrero del año 21. La re. clusión del autor de Los Heraldos Negros había provocado inmediatamente la protesta de los intelectuales trujillanos, encabezados por A. Orrego y J. E. Garrido, los cuales, sin interesarse mayormente por el esclarecimiento jurídico de los hechos, llevaban el asunto a un "plono ético superior", garantizando la moralidad cotidiana del acusado. En Lima, la Federación de Estudiantes también interviene y, al otro extremo del país, en Arequipa, el poeta Percy Gibson obtiene que el Presidente de la Corte Superior local responda de Vallejo frente a la Corte de Trujilo, donde el Fiscal interino, Doctor Castañeda, "opina por la improcedencia del juicio", y el abogado del poeta, después de un último recurso público, logra que el preso salga de la cárcel en la fecha susodicha.

$\mathrm{Si}$ el incendio de la Casa Santa María en Santiago permanece envuelto en las tinieblas del procedimiento judicial, la simpatía espontánea que Vallejo entonces encontró entre los representantes más activos de la intelectualidad peruana de la época es en cambio explícita y reveladora.

Para terminar con el proceso del Trujillo, advertiremos que nunca había de concluír o más bien que sólo acabó por prescripción en el año 1928. Entre tanto, Vallejo había aprovechado su libertad condicional para irse del Perú y es probable que la amenaza latente que sentía sobre su persona a pesar del arreglo jurídico provisorio harya contribuído en acelerar los preparativos del viaje a Europa. De igual manera la prolongación de una situación legalmente imprecisa impidió al poeta, durante muchos años, pensar en $\epsilon$ regreso a su tierra, y hasta le llegó a inquietarlo en varios momentos de su permanencia en Francia : una serie de cartas cambiadas con su antiguo abogado, Carlos Godoy, entre junio y agosto de 1926, resulta particularmente elocuente al respecto, en una fecha en que el Tribunal de Trujillo había ordenado nuevamen. te la captura del escritor y lanzaba comunicaciones concordantes a los consulados del Perú en París y en Madrid.

La última visita a Santiago de Chuco y la prisión subsecuente en la cárcel de Trujillo también tuvieron consecuencias duraderas en la obra literaria de Vallejo quien en la página de Poemas Humanos titulada El momento más grave de la vida escribiría todavía, con referencias inequívoca: "El momento más grave de mi vida fue mi prisión en 
una cárcel del Perú". En los tres meses y medio de su permanencia entre "las cuatro paredes de la celda", Vallejo ha compuesto gran parte de los poemas de Trilce, algunos de los cuales (Tr. XVIII - XXII - L - LVIII) evocan las impresiones directas del hombre recluído por los demás. En la cárcel igualmente Vallejo escribió la primera serie de los cuentos de Escalas Melografiadas.

Este último libro revela en el campo de la prosa algunas preocupaciones estéticas, y sobre todo idiomáticas paralelas a aquelias que ciominan los versos publicados en 1922. Creaciones de palabras o empleo inédito, de las mismas, imágenes abstractas rebelcies a cua:quier clase de representación aparecen tanto en los cuentos de la primera parte: Cuneiformes (apenas si son cuentos), como en los de la segunda: Coros de Viento, más literarios y elaborados y probablemente escritos después de la permanencia en la cárcel, con la atmósfera de la vida diaria, en la cual se insinúan a cada instante los presentimientos del mundo del dolor, de la locura y de la muerte. En los momentos menos esperados, Vallejo prorrumpe a "guillotinar sílabas, soldar y encender adjetivos", tal como lo hace un personaje de Los Caynas : el poeta percibe sonidos "trágicos y treses", la sed "ensahara" la garganta, la linterna es "ojitrista", los ojos, "entelerañados". las lomas, "onfaloideas" $Y$ el talento "grandeocéano"; entonces encontramos igualmente frases como las siguientes "Aposéntome bajo uña índigo del firmamento y en las 9 uñas restantes de mis manos, sumo, envuelto y arramblo los dígitos fundamentales, de 1 en fondo hacia la más alta conciencia de las derechas", o: "joh "mi bohemia de entonces,... el círculo de mi cara libertad de hombre a dos aceras de realidad hasta por tres sienes de imposible!".

Una vez salido de la cárcel, Vallejo vueve de Trujillo a Lima: en los meses siguientes termina su libro de poemas; también escribe algunos de los cuentos que integrarán Coros de Viento y manda uno de ellos, el titulado: Más alló de la vida y de la muerte, a un concurso organizado por la Sociedad Cultural "Entre Nous" en el mes de diciembre de 1921. El cuento del autor de Los Heraldos Negros se lleva el primer premio en el certamen, y con el dinero entonces recibido, Vallejo prepara la publicación de su segunda obra poética cuyo título él mismo no conoce todavía; finalmente es una inspiración fortuita del último momento la que sugiere el nombre: Trilce, neologismo numérico excepcionalmente feliz para introducimos $\alpha$ un libro en el cual las palabras surgen muchas veces sin ser anunciadas y el vocabulario aritmético cobra una vida no acostumbrada; el volúmen estaba casi terminado de im. primir y no llevaba título definitivo cuando, un día en el taller mismo don- 
de se hacía la impresión, el poeta de pronto exclamó: "En tres soles se va a vender. Entonces se le va a poner Trilce".

La muerte de la madre y la permanencia en la cárcel han agudizado el dolor del hombre para quien una experiencia puramente intelectual o un consuelo de orden filosófico son propiamente inconcebibles. Desde las primeras páginas de "Escalas Melografiadas" las sensaciones de la "celda" están ligadas a las sensaciones del comer o como dice a menudo Vallejo, del "Yantar"; en Alféizar especialmente, el recuerdo de la infancia y de la madre invade una escena de la cárcel, con el sabor del pan caliente que se comía en Santiago de Chuco a la hora del desayuno. Una emoción de ternura angustiada es la única respuesta al "yo no sé" definitivo que el huérfano repite en presencia de la vida. "El hombre... que no sabe ni sabrá jamás qué hora empezamos a vivir, qué hora empezamos a morir, cuándo lloramos, cuándo reímos, donde el sonido limita con la forma en los labios que dicen: yo...", el hombre incapaz de juzgar o de comprender, y siempre envuelto en a!go hostil qua no logra identificar, el hombre pues, no conserva sino una piedad inmensa que la prisión y el contacto con una humanidad condencrda vuelve aún más fervorosa y profundamente sentida: "La justicia... no se ejerce, no puede ejercerse por los hombres, ni a los ojos de los hombres. Nadie es delincuente nunca. O todos somos delincuentes siempre" (Muro Noroesste). Piedad que no cesa en el día de la liberación, sino que vuelve a manifestarse $\alpha$ cada instante cuando el poeta corrige las pruebas de Trilce en los Talleres Tipográficos de la Cárcel Central de Lima, el Panóptico: el jefe del taller es un "un penitenciado, un bueno, como lo son todos los delicuentes del mundo" (Liberación). Piedad que surge en cualquier momento y en cualquier lugar, en la cárcel pero también en el manicomio como en Los Caynas.

La vida se resume en una sensación de abandono o, por ratos, de bienestar. El amor, celebrado en Mirtho se confunde con la proximidad del vientre de la mujer amada, "más palpitante que el corazón, corazón el mismo" (cf. unas líneas más abajo: "A Dios sólo se le puede hallar en el vientre de la mujer!" ). La piedad y la ternura nacen de esa sensación de calor o de frío, de hambre o de satisfacción : "...siendo buenos y puros con pureza intangible de animales..." (Muro Antártico). La "obsesión zoológica regresiva" que se ha propagado entre los habitantes de Cayna, a partir de Luis Urquizo, aquel personaje que todo lo pone al revés, ríe en el dolor, llora en el placer y descubre el triángulo de dos ángulos, - y asimismo el grito patético : "Todos nosotros somos hombres!" que el autor de la narración de Los Caynas lanza como un exorcismo frente al pueblo entero que imagina ser un pueblo de mo. 
nos, distan mucho de presentar solamente un interés anecdótico: "Tengo un miedo terrible de ser un animal..." rezará un poema de Poemas Humanos, y la poesía última de Vallejo se situará en este mismo nivel de humanidad total, corpóreamente experimentada, al mismo tiempo amenazada y redimida. (4).

Trilce sale a luz en 1922. Las reacciones de la crítica son generalmente hostiles o irónicas. Los lectores de Chocano se burlan del "poeta sin poemas" (es decir sin poemas para ser recitados): la poesía de Eguren, a pesar de su extrañeza, mantiene una apariencia coherente, la de Vallejo desconcierta, tanto por su "incoherencia" como por las cudacias verbales que constantemente revela.

El viaje a Francia, en el cual el escritor pensaba al menos desde 1920, se vuelve para él cada día más imperioso: después de publicar Fabla Salvaje y Escalas Melografiadas y de reunir a duras penas el dinero indispensable para la travesía, Vallejo logra finalmente embar. carse el 17 de Junio de 1923, a bordo del vapor "Oroya".

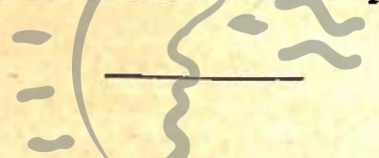

Para quien abre Trilce por primera vez, la importancia excepcional de la palabra, del vocablo considerado en sí mismo y por sí mismo salta inmediatamente abla vista. Vallejo no recibe el lenguaje como u-

\section{"Jorge Puccinelli Converso»}

(4) El libro llevaba como prólogo unas páginas proféticas del amigo de Trujillo, Antenor Orrego, quien insistia en la "virginidad poética" y la "puerilidad genial" de un poeta para el cual no encontraba precedente en América Latina : "Sus palabras no han sido dichas; acaban de nacer. El poeta rompe a hablar porque acaba 'de clescubrir el verbo...". Pero, a pesar de la presentación aguda y amistosit, Trilce no iba a encontrar simpatía, sino bajo la pluma de Luis Alberto Sánchez en Mundial : un poco más tarde, unas conferencias de Sánchez en Colombia y el elogio inesperado dé Vallejo én los Juegos Florales de 1924 no bastarían para disipar la reprobación o la indiferencia generat. Habrá que esperar los últimos años de la década r920-1930 para que Ia obra de Vallejo, o principalmente su ejemplo, empiezen a repercutir en un público más amplio. Quien inicia ese primer momento de interés por la poesía valtejiana és nueviamenté L. A. Sánchez, el cual advierte la emoción auténtica de una poesía de angustia y de abandono que nunca se deja guiar por preocupaciones únicamente artísticas (Mundial - I8 de noviembre de 1927; un año antes - 20-VIII-1 926- la misma revista habia reproducido dos poemas de Los Heraldos Negros : Pasos Lejanos y Agape, también presentados por Sánchez).

Los dos estudios más importantes de esta época (la época de Amauta y de las revistas socialistas o indigenistas) son los de José Carlos Mariátegui en "El Proceso de la Liseratura Peruana (Siete Ensayos - 1928) y de Jorge Basadre en La Sierra de febrero de 928 (artículo titulado $U n$ poeta periano); ambos autores, llevados por la orientación 
na riqueza formada de antemano, que se trataría entonces de utilizar en la mejor forma posible, sino que lo ve nacer y morir ante sus ojos, dotado de una existencia inquietante, tom inquietante como la existencia misma. El poeta no hereda un idioma ya completo con su código de usos y significados: lucha con elementos que imumpen para luego desaparecer y que él trata de retener cuando le escapan, o de agotar cuando lo obsesionan.

Vallejo confesaba un día a Ernesto More que se sentía "huérfano del idioma": semejante orfandad coincide admirablemente con la orfandad más general que le hemos visto experimentar frente a la vida, aún antes de morir su madre. Sabemos (y es esta casi la única confidencia de sus amigos que sale de lo vulgarmente anecdótico), sabemos que, en Lima y más tarde en París, el autor de Trilce cogía a veces una expresión corriente y la repetía lentamente hasta el hastío, como para revelar la esencia misteriosa y animada del vocablo: "Vallejo, nos dicen, volatilizaba la palabra".

Las expresiones que hemos oído volver con cadencia de obsesión en algunos poemas de Los Heraldos Negros se relacionan con esta particularidad que Trilce lleva hasta su límite. "La-pla-ta" decía por ejemplo Vallejo en presencia de un amigo, y luego repetía las tres sílabas, acentuando y destacándolas hasta cansar a quién lo oía; otras veces multiplicaba la última vocal de una palabra: "Yo... Yoo... Yoo०...

del momento, exageran "quizás qa importancia del "localismo" en los poemas de Vallejo, sin caer sin embargo en las generalidades apresuradas que estarán de moda una década más tarde. En 1930, la segunda edición de Trilce en Madrid, acompañado de un prólogo de José Bergamín, constituye como el primer reconocimiento internacional del poeta peruano : el prologuista recalca sobre todo la originalidad del lenguaje, despojado, seco, ardoroso, más próximo al grito salvaje que a la palabra continuada.

Mientras tanto la evolución política de Vallejo, la publicación de Rusia 1931 y la de Tungsteno, saludada por un artículo del compañero trujillano, Alcides Spelucín, originan un nuevo período de ocultación poética : en Francia y en España el autor de Trilce se pierde en el anonimato del hambre y de la miseria. No obstante, lejos de los campos de batalla europeos, los primeros libros de Vallejo solicitan la atención de un público reducido pero que prepara los caminos de una mayor atención : cn su estudio : Panorama actual de la poesía peruana (1938), Estuardo Núñez, sin estudiar especialmente Los Heraldos Negros y Trilce, los señala como punto de partida de las tendencias principales que él descubre en los poetas de los últimos años, $y$ en 1939, Carlos Cueto dedica a Trilce uno de los pocos artículos que, en adelante y por varios años, no se someten a imperativos extraliterarios o artísticos.

Efectivamente, la muerte de Vallejo en plena guerra española y la publicación de sus poemas póstumos en una edición limitada que muly pocos lectores conocerán en el Perú son el pretexto de una serie dé artículos periodísticos que sè ocupan del destina del poeta 
Yoooo...". Uno pensaba, declara Ernesto More, que jugaba con las pabras, lo mismo que un niño con sus juguetes hasta dejarlos despedazados.

Este carácter de la poesía de Vallejo, que pone en tela de juicio todas las formas, inclusive las que parecían tan naturales que nos olvidábamos que también eran formas (los vocablos) es el que más ha impresionado a los comentaristas españoles, quienes, después de Bergamín, han querido reconocer en él el indicio de un hombre americano. El mismo Vallejo, consciente de los peligros que amenazaban su poesía, los enfrentaba sin embargo como una obligación artística imposible de apartar. Algunas líneas de la carta escrita a Antenor Orrego, después de la publicación de Trilce permanecen con el tiempo reveladoro.s:

El libro ha nacido en el mayor vacío... Asumo toda la responsabilidad de su estética. Hoy y más que nunca quizás siento gravitar sobre mi, una hasta ahora desconocida obligación sacratísima, de hombre y de artista, la de ser libre. Si nó he de ser hoy libre, no lo seré jamás... Me doy en la forma más libre que puedo y ésta es mi mayor cosecha artística... ¡Dios sabe cuanto he sufrido para que el ritmo no traspasara esa libertad y cayera en libertinaje! ¡Dios sabe hasta que bordes espeluzantes me he asomado, colmado de miedo, temeroso de que todo se vaya a morir a fondo para mi pobre ánima viva...!".

No hay que olvidar el nacimiento solitario de Trilce, que difícilmente hubiera podido nacer en otra época que aquella en la cual fué escrito, pero que no tiene equivalente en la poesia de habla castellana.

mucho más a menudo que de sus escritos, La Profecía de A mérica de Juan Larrea (Revista de las Españas - Barcelona - 1938) indica el alcance universal de la vida de Vallejo, pero los homenajes líricas que empiezan a tributársele en su tierra natal prescinden casi por completo del texto mismo de la obra conocida sobre todo, a partir de $19+2$, a través de la Antología Poética de Xavier Abril.

La primera tesis universitaria sobre Vallejo, la de Alberto Mendoza, ( 194.1 ) nace en ese ambiente. Constituye de todos modos, un punto de partida, ya que, solamente en Lima, la siguen las tesis de Antenor Sámaniego ( $94+7$ - publicada en r954) y de Elsa Villanueva (r948- publicada en r95I). Pero hacia falta emprender un estudio más directamente atenido a la escritura particular de los poemas, y cuyo ejemplo encontrábamos en la breve nota de Emilio Adolfo Westphalen : Un poema de César Vallejo vertido al frantcés (Correo de Ultramar - $19+7$ ). Mis primeros artículos sobrc el poeta de Santiago de Chuco han coincidido con la publicación de la edición Losada de los poemas y con las Notas de entrada escritas en España por José María Valverde, cuyas impresiones corroboran muchas veces las mías, y desde entonces ha salido en los Estados Unidos la primera monografía general sobre Vallejo, firmada por el Profesor Luis Monguió. La obra poética de Vallejo ha entrado últimamente en el campo de la crítica objetiva y desapasionada. 
¿Qué podemos conocer más precisamente del medio intelectual en el que bruscamente apareció? Los recuerdos de los sobrevivientes no tienen casi nada que enseñamos. Y si acudimos a las publicaciones peruanas de la época, que generalmente son revistas para gran público, comprobamos en ellas, como era de esperar, la supervivencia de estéticas en otros lugares pasados de moda.

Valdelomar ha logrado finalmente imponerse, pero aquellos que lo aceptan desconfían automáticamente de cualquier joven poeta que pudiera renovar o prolongar su tentativa iconoclasta; él mismo muere, como ya lo señalamos, en el año 1919, dejando un gran vacío en el campo de las letras. Es el momento en que Clemente Palma dice una vez más: "Hoy la mayoría de nuestros poetas jóvenes escriben versos pero no hacen poesía" - lo que podría ser una perogrullada en cualquier momento, pero que, bajo la pluma del director de Variedades, es más bien una defensa de todo lo pasado contra todo lo presente.

En realidad, el reino de Chocano continúa: la noticia de la prisión del poeta en Guatemala, después del derrocamiento de Estrada Cabrera (agosto de 1920) conmueve profundamente la opinión y cuando, en septiembre del año siguiente, se anuncia el regreso al Perú del vate liberado, éste lanza personalmente una propaganda que lo compara con los grandes presos de la historia literaria de todos los tiempos y todos los países: El Tasso, Camoens, Villon, Cervantes, Chénier, Wilde. La detención de Chocano y la de Vallejo, a unos meses de distancia, presentan asimismo los caracteres más opuestos. La llegada de Chocano a Lima, a fines de 1921, daquiere contornos triunfales: en el número del 17 de diciembre de la revista Variedades podemos por ejemplo ver al poeta fotografiado en cada momento de su primer paseo a través de la ciudad, al lado de todos los monumentos públicos, y unos meses más tarde, en noviembre de 1922, el año de gloria culmina en la apoteosis : la coronación de Chocano como poeta de América.

En una profesión de fe que constituye un documento quizás único de autoglorificación descabellada, el autor de Alma América tiene aquel día la oportunidad de compararse con Santa Rosa de Lima, y, en forma incidente con el mismo Cristo: "El Perú debe ufanarse de la corona de laureles que ciñe a su poeta (es Chocano quien habla de Chocano), como se engríe de la de espinas que ajustara las sienes de su santa.. Las coronas de Cristo y Apolo son las dos únicas coronas que no han caído ni caerán jamás al empuje de las Revoluciones...". El sentido del ridículo faltaba por completo en aquella oportunidad al héroe de la ceremonia, y también a los que lo felicitaban, pues se encontró quien escribiera una "ofrenda al poeta" que termina con estas palabras: "Pa- 
dre nuestro que estás en el verso. glorificado sea tu nombre, ahora y siempre, por los siglos de los siglos. Amén". Eran estos los días en que Vallejo ingresaba a la cárcel de Trujillo.

El primer libro de Alberto Guillen, ya lo vimos, rompía con el simbolismo, relacionándose más bien con una tradición de poesía voluntaria, varonil, armada de ideas y de afirmaciones, a la manera de Whitman; por una tendencia egolátrica evidente conservaba puntos de contacto con Chocano (en 1925 Guillén publicará: Imitación de Nuestro Señor Yo). mientras que, por el altruísmo que tonificaba su egotismo, y por el sentimiento fraterno que trataba de expresarse en una nueva forma épica, se emparentaba con una corriente más general de la poesía del tiempo de guerra y de postguerra. En 1920, Guillén publica un segundo libro : Deucalión donde revela una forma más mesurada de su talento - poemas cortos, cuidados, filosóficos que son generalmente bien acogidos por la crítica: Ventura García Calderón felicita al poeta por lo que él considera como un progreso hacia la madurez pero concluye su artículo con una generalización que con la distancia nos parece singularmente aventurada: "Ya en Francia asistimos a una resurreción del alejandrino y de las modas de 1830 .. . a pesar de los vientos de sedición de días anteriores a la guerra" (5) En adelante Guillén recibirá la mejor acogida en las revistas de la época, y en 1921 se embarca para Francia y España, no teniendo en común con Vallejo sino el hecho anecdótico de partir los dos para Europa en fechas relativamente vecinas.

En cuanto a Alberto Hidalgo se ha establecido desde 1918 en Buenos Aires, donde los contactos con Europa son más frecuentes que en Lima. En la capital argentina, el autor de Panoplia Lírica levanta polémicas que interesan a la literatura peruana y simultáneamente recibe las últimas influencias que llegan del "viejo mundo" sin abandonar una actitud fácil de provocación intempestiva ("Lo siento, pero tengo más talento cada hora que pasa", escribe a Gómez de la Serna cuando prepara química del espíritu). Pero es de notar que, no obstante la actitud de desafío, ninguno de los libros poéticos de Hidalgo publicados hasta 1922 (Las voces de colores -1918- Joyería -1919- Tu libro -1922) manifiesta las audacias estéticas que permitirían incluir a su autor en lo que se conviene entonces en nombrar "las gestas de vanguardia" de habla castellana. Es solamente en 1923 (posteriormente a Trilce) cuando aparece : química del espíritu - utilizando los recursos tipográficos nuevos del lirismo de postguerra con una agilidad a veces desconcer-

(5) En "Variedades" - Agosto de x92x. 
tante, pero que nos hace sentir mejor la originalidad propia del libro de Vallejo: la aparición del lenguaje matemático o de las imágenes dinámicas va siempre acompañada en los poemas de Hidalgo por una estructura discursiva que se desarrolla sin misterio ni sombra. Química del espíritu puede ser todavía interesante desde un punto de vista histórico como representativo de una época determinada, mientras que Trilce, por el tono mismo que lo caracteriza, sostiene un interés permanente que no puede ser agotado.

En la fecha en que fué publicada la obra de Vallejo, los contactos que un lector limeño podía establecer con los movimientos europeos contemporáneos eron de todos modos reducidos. Algunos peruomos de viaje mandaban a veces artículos a las revistas de su tierra, pero dichos artículos no pasaban por lo común de someros y superficiales: en enero de 1921, encontramos por ejemplo en Mundial un artículo de Antonio Garland, titulado: "Al margen de las estéticas inquietistas: Le nouvelle (sic) esprit"; después de presenciar en Barcelona una exposición de arte moderno, el autor se contentaba con señalar unos nombres: cubismo, primitivismo, ultraísmo, etc., sin indicar lo que representaban. En noviembre de 1922, en la misma revista, Juan de Egas advierte: "Es hora que lleguen al Perú movimientos cuyos iniciadores ya mueren en Europa... que ya logran toda su fuerza en Chile y Argentina... ¿Qué sucedería de aparecer en Lima poeta verdaderamente dadaísta, ultraísta o creacionista? Se dudaría de su razón seguramente...". Pues bien, al publicarse este último artículo. Trilce ya había sido escrito, Trilce que no era por cierto dadaísta, ni ultraísta, pero salía a la luz en el momento adecuado y llevaba como desconcertar al público lo mismo que una obra "verdaderamente" dadaísta o ultraísta.

Los poetas que, a raíz de la segunda guerra mundial, forman en España el grupo ultraísta no empiezan a reunir en libros sus producciones anteriores sino a partir del año 1922. Cuando Vallejo escribe Trilce, el ultraísmo, cuyo nacimiento coincide con la primera manifestación colectiva de enero de 1919, se encuentra, pues, todavía en el período de las revistas y lo que el poeta peruano pudo alcanzar del movimiento peninsular lo conoció hojeando, en una librería como la "Aurora Literaria", las pocas publicaciones españolas que ahí llegaban, sin que podamos fijar exactamente qué números de Grecia y Cervantes (bocinas dadaístas de 1919 y 1920) o de Ultra (fundada en 1921) vinieron hasta Lima.

Por otra parte, la culminación en Trilce de ciertas particularidades ya patentes en Los Heraldos Negros, tanto como la desaparición del autor durante largos meses después de los incidentes de Santiago de Chuco y el hecho de haber sido escritos muchos poemas en la época 
del encarcelamiento en Trujillo preservan el aspecto insólito del libro de Vallejo, cuya originalidad, en medio de toda la producción contemporánea de vanguardia, nunca ha sido puesta en tela de juicio. "El Ultraísmo, escribe Guillermo de Torre, ha tendido preliminarmente a la rehabilitación genuina del poema. Esto es a la captura de sus más puros e impercederos elementos - la imagen, la metáfora - y a la supresión de sus cualidades ajenas o parasitarias: la anécdota, el tema narrativo, la efusión retórica". (6) La necesidad de liquidar la herencia del siglo XIX es sensible en todos los poetas de aquel entonces $\mathrm{Y}$ Vallejo participa en ese movimiento general que suprime la rima, los ritmos regulares, "las cadenas de enganches sintácticos y las fórmulas de equivalencia", suprime o al menos utiliza libremente la puntuación, da una importancia nueva a la grafía poética (espacios, líneas en mayúsculas, escritura vertical, diagonal etc.), deja de tener en cuenta las cualidades musicales y auditivas del poema, para suscitar al contrario una "arquitectura visible". Pero entre Trilce y las composiciones uliraístas no hay casi nada en común fuera de la voluntad extremada de liberación y de correspondencias ante todo formales.

Vallejo no suprime deliberadamente la anécdota y basta echar una ojeada rápida sobre Trilce para comprobar que los poemas no persiguen imágenes y metáforas con valoración inmediata (según lo anteriormente afirmado por Guillermo de Torre) - breves hallazgos líricos acumulados tales como podemos reconocerlos en los poemas ultraístas de Jorge Luis Borges o de Gerardo Diego. El carácter a menudo abstracto del vocabulario de "Trilce y lef esfuerzo del poeta por dar una nueva forma al lenguaje mismo, al igual que las relaciones entre este último libro y el primero de Vallejo, son suficientes para designarle sitio aparte en la producción de la época. En su segunda obra poética, Vallejo ha madurado una experiencia esencialmente solitaria.

\section{II.- LOS 5 POEMAS INICIALES}

El autor de Trilce ha renunciado a los títulos de los poemas y a la división del libro en secciones como las que encontramos en Los Heraldos Negros. Las 77 composiciones que integran la obra (el total no es indiferente) se distinguen únicamente por un número; la mayor parte

(6) Guillermo de Torre : Literaturas Europeas de Vanguardia. Madrid, Caro Raggio. 
de ellas no tienen "materia" en el sentido tradicional de la palabra y darles títulos separados hubiera llevado al poeta $\alpha$ inventar en cada caso una palabra nueva tal como lo hiciera en Canciones de Hogar y en la elección del vocablo Trilce. Desde el primer poema resulta también evidente que el artista, a pesar de vivir en una atmósfera siempre impregnada de influencias modernistas, ha rechazado definitivamente la selección previa de los elementos considerados como estéticos 0 , al contrario, no estéticos.

Finalmente la liberación de la métrica tradicional es afirmada de un extremo a otro de la obra; cada poema crea su ritmo propio según las exigencias del momento, y si queremos establecer a toda costa los últimos puntos de referencia con la poética anterior, apenas podemos advertir en alguna que otra página la predominencia de un metro particular ( $p$. ej. el endecasílabo en $T r$. XXXIV), la tentativa de organización en estrofas más o menos regulares ( $\mathrm{p}$. ej. Tr. XLIX) o el recuerdo de composiciones de forma fija ( $\mathrm{p}$. ej. el soneto en Tr. XXXIV y Tr. $X L V I)$.

Si examinamos ahora la disposición de los poomas en el libro, encontramos un orden aparentemente arbitrario, que no obedece a ningún criterio externo u objetivo. Por toda la obra corre aquel estremecimiento humano que, según palabras de Bergamin, la determina; sin embargo la unidad fundamental no oculta la diversidad de la expresión poética y la existencia de algunos temas particulares, ya conocidos en Los Heraldos Negros (la madre, la niñez, el hambre, el amor) o más recientemente adquiridos (la cárcel por ejemplo), los cuáles establecen entre los poemas relaciones que hubieran podido manifestarse en la estrucra general del libro. En un estudio detallado, no será inútil agrupar los diferentes trozos para examinar varios conjuntos, unidos por ciertos rasgos comunes de inspiración y de emoción. No olvidaremos tampoco que los poemas más audaces, si no siempre los más humanos, de Trilce se caracterizan principalmente por un empleo insólito del lenguaje, sin consideración de tema o de materia determinada: contribuyen a la fiscnomía propia de la obra y debemos examinarlos con igual atención que los demás, evitando la selección previa de las composiciones, principal defecto de las antologías poéticas de Vallejo, hasta la de Monguió, que desechan casi por completo los poemas más difíciles, para considerar tan sólo aquellos cuya motivación sentimental es inmediatamente perceptible (1).

(x) En sus Notas de entrada a la poesía de Vallejo, J. M. Valverde, quien por lo demás no pretende hacer un estudio exhaustivo, seliecciona igualmenté los poe- 
A través de los cinco poemas iniciales que desconciertan, cada uno en forma diferente, al lector no preparado, nos formaremos una primera visión de Trilce, insistiendo tanto en la variedad como en la originalidad propia del libro de Vallejo.

La primera palabra del primer poema es tan característica como la primera de Los Heraldos Negros, "Quién...": la interrogación del principio reaparecerá en más de una oportunidad para iniciar los poemas siguientes del libro. (2) Como punto de partida tenemos una sensación, no por cierto una sensación compleja, visual por ejemplo con fines descriptivos (ya se ha advertido el carácter muy poco visual de la poesía de Vallejo, poesía sin formas ni colores), sino una sensación auditiva confusa, experimentada como algo molesto que el ser humano sufre en forma violenta, fuera de todo elemento de juicio o de representación: la palabra "quién" corresponde a un momento casi tan primitivo como el "Yo no sé"; la interrogación surge de la afirmación de todo lo que amenaza al poeta para siempre, y la "bulla" viene a ser como la materialización momentánea de aquella amenaza elemental, que el segundo verso del poema relaciona con una actitud corpórea determinada : el hombre está tomado en el acto humilde (?) del defecar; Tr. 1 es un poema de la defecación transpuesta en términos universales, cósmicos.

Los versos siguientes, a primera vista tan desconcertantes, se abren a la interpretación en cuanto los consideramos desde ese punto de vista. La oscura amenaza que no se deja dilucidar por la conciencia influye en una función primitiva del hombre, igualmente muy poco consciente, y que se pierde en la experiencia vaga del paisaje costeño del Perú (las islas guaneras y las aves que en ellas habitan colaboran con los datos humanos anteriores y se superponen para crear imágenes como: "en el insular corazón, salobre alcatraz..."). Tenemos desde luego que situar todo lo dicho en un clima de inocencia pueril, que vemos reivindicado por ejemplo en Tr. XIX, con versos poéticamente dudosos pero de todas maneras explícitos: "El establo está divinamente meado $y$ excrementido por la vaca inocente $y$ el inocente asno y el gallo ino-

mas con un tema fácilmente identificable. En cuanto a Monguió dedica un capitulo de su obra a "la técnica de Trilcc", pero se contenta con analizar Tr.II, cuya estructura podemos todavía relacionar con algo anteriormente conocido.

(2) La desaparición del signo de interrogación es uno de los fenómenos más constantes de la libertad del poeta frente a la puntuación tradicional: la advertimos sobre todos en los poemas más dislocados de Trilce, y posiblemente el estudio detenido de la puntuación nos ayudaría a establecer una dlasificación cronológica de los distintos trozos del libro. 
cente" (véase también: Tr. LIII: "su estímulo fragante de boñiga, etc-). En el presente caso los diferentes elementos se entremezclan en forma menos objetiva pero inmediata como pueden hacerlo en el pensamiento semielaborado de un niño, que no separa exactamente su cuerpo del mundo exterior, y para quién todo se reduce a la emoción imprecisa de un acto todavía animal y de lo que viene a perturbarlo. La súplica : "Un poco mós de consideración..." parte de dicha emoción; no es sino un balbuceo inconcluso que se agota en el instante, en la presencia obsesiva de los excrementos: " $y$ el mantillo líquido... y la península...".

A través de una situación particular, nos encontramos nuevamente situados al origen corpóreo de la conciencia, en un poema del cual toda clase de elaboración intelectual ha sido descartada. Las demás características del poema, y especialmente su estatuto verbal propio, se explican por el hecho fundamental que advertimos : señalemos de una vez por todas la utilización del lenguaje hablado, hasta la incorrección o ia licencia gramatical ("en cuanto será tarde..., la península párase..."); más importante es el empleo de palabras raras con valor auditivo ("hialóidea grupada") y la creación simultánea de expresiones que emotivamente les corresponden ("calabrina tesórea"). El lenguaje nace al mismo tiempo que el poema y el vocablo muchas veces se presenta, como cogido cuando no inventado, por su figuración propiamente sensible y nol representativa. En otros momentos, tal vocablo invoca a otro de un modo casi mecánico y los dos vocablos asociados provocan una tensión intelectualmente sin solución ("en cuanto será tarde, temprano..."). Finalmente una palabra substituye a la palabra que normalmente se esperaba, el vocabulario de los distintos sentidos se superpone, y, alcanzamos una evocación del crepúsculo, tal como puede darse en esa poesía con escasos recursos visuales : matices afirmados pero no enumerados (bemoles) con un solo adjetivo descriptivo (soberbios) ("seis de la tarde DE LOS MAS SOBERBIOS BEMOLES": el uso de la mayúsculas - frecuente en "las estéticas de vanguardia"tiende a imponer la sensación, la cual irradia sobre el poema entero, dominadora e incontrastable).

Era necesario marcar desde el principo la importancia de todos esos procedimientos verbales, al nivel de la obsesión fundamental que sigue desde la primera hasta la última página del libro: con Trilce el lenguaje mismo en su estructura lógica ordinaria entra en tela de juicio sin que logren siempre "testar las islas que van quedando" de las formas lingüísticas acostumbradas, formas para la mayor parte de los hombres tan naturales como el hecho permanente de existir. 
De esta lucha con el lenguaje, Trilce II nos ofrece un testimonio por completo diferente: en las tres primeras estrofas es fácil señalar los elementos de un cuadro impresionista, pero que no logra del todo objetivarse $y$, desde el primer momento, cede ante una instancia poética más profunda o primigenia; la obsesión creada en la mente del poeta por algunos vocablos especiales (acordémonos de aquella "volatilización del lenguaje" a la que Vallejo se entregaba en la vida diaria) es contemporánea de la visión, y los detalles mismos de la visión existen no tanto por su calidad propia como por ser efectivamente materia prima obsesiva; el estancamiento especial del mediodía -tiempo inmóviles inmediatamente asociado con la palabra misma "tiempo" que, repetida sin que haya progreso alguno, se vuelve en esa forma el signo de la obsesión. "Era" y "mañana" - el pasado y el futuro-contribuyen luego a un fin paralelo. Estamos siempre dominados por el presente, cuyo imperio es experimentado de un modo tiránico en todo aquello que él pierde y niega.

De la impotencia frente a semejante dominación del tiempo surge la pregunta final: "¿Qué se llama cuanto heriza nos?"; lo incorrecto - incoherente del verso acentúa la imperfección del lenguaje cuando trata de nombrar lo innominable, es decir aquella amenaza impersonal a la cual aludimos anteriormente como continuamente asumida por el poeta, y la respuesta que viene en seguida, no elucida el terror tanto como lo justifica ila substantivación de una expresión pronominal, neutra e indefinida "Tomismo" al mismo tiempo que confiere $\alpha$ dicha expresión vida propia, autónoma (para Vallejo las palabras - muchas de ellas abstractas- cobraban de pronto un significado vital y lógicamente insospechado), deja subsistir una angustia, más temible aún que en la confesión de ignorancia de Los Heraldos Negros, El poema se detiene en la palabra "nombre", cuatro veces reiterada, es decir precisamente en la ausencia de un "nombre" que pueda designar el sujeto de esa angustia.

Con Trilce III, entramos en un universo si no de fondo, de expresión menos atormentada: las palabras de cada día, las palabras humildes del vivir cotidiano aparecen naturalmente y nos acordamos de la tonalidad afectiva de los últimos poemas de Los Heraldos Negros; el sentimiento particular del tiempo que marcaba los versos finales de A mi hermano Miguel encuentra ahora su traducción más perfecta. Vallejo siente el tiempo en la destrucción continuada del presente : al escribir un poema de la niñez, como el que comentamos, no le corresponde, 
pues, evocar la niñez en un pasado objetivamente abolido, sino que literalmente vuelve $a$ vivir su infancia, o mejor dicho la sigue viviendo como que nunca se ha separado de ella en absoluto. No es un hombre maduro, un hombre de cuerpo adulto el que está hablando; es el niño de siempre que persiste realmente bajo la apariencia del hombre.

Ningún poema del libro capta de modo tan directo el dudar propio de los niños que empiezan a dialogar (?) o más bien a contarse a sí mismos sus primeras razones y sus primeras penas : a partir de la interrogación anheiante de la estrofa inicial, los movimientos mismos del ritmo, la progresiva amplificación que arranca en el quinto verso, las exhortaciones súbitas y luego la repetición obstinada ("madre dijo..." etc.), con la escena muda que no es difícil reconstituir a través de los silencios del hablar: pasos, miradas ademanes, finalmente la reivindicación sensible en la penúltima estrofa, antes de que volvamos para terminar a algo más jadeante $y$ angustiado - todos esos movimientos sucesivos indican momentos vividos, avances y retrocesos, esperanzas y fracasos. El lenguaje empleado es igualmente un lenguaje de niño, con giros familiares ("todo el santo día"), algunos peruanismos ("aquí no más"), las interrupciones sintácticas ("¡el mío es más bonito de todos!") y las imitaciones del lenguaje lógico de los adultos ("como debe ser").

La infancia toda se entrega en los versos del poeta: confianza irracional ("Madre dijo que no demoraría") y asimismo congoja inexplicable en medio de las tinieblas del abandono, pero en esa incapacidad para superar los temores y los anhelos irreflexivos se afirma igualmente la condición misteriosa del hombre con su temible proximidad, y podemos percibir la conexión de la experiencia infantil de Valiejo con su experiencia permanente : una declaración como la tantás veces citada de Nostalgias Imperiales: " y lábrase la raza en mi palabra" no nos conmueve mayormente por lo mismo que tiene forma de proclama; en cambio basta que el poeta abandone cualquier proyecto de definición para que su verbo más íntimo y auténtico exprese al mismo tiempo que el alma de su propia niñez todo lo que en ella corresponde con el alma de un pueblo que vive al margen de nuestras explicaciones racionales, en contacto con las fuerzas irrebatibles del mundo circundante, ora benevolentes, ora hostiles (3); es entonces igualmente cuan-

(3) Véase por ejemplo Fabla Snlvaje. En el poema que ahora consideramos, al lado de las "personas mayores", ausentes pero otras veces tutelares, tenemos a las almas muertas, "las penas", que pasan sembrando el pavor, y dotadas de una existencia tan afectiva como las primeras, salvo que estas, al contrario, participen del modo de ser aterrador de las penas. 
do Vallejo se deja oir por todos aquellos que pueden reconocer, por debajo del universo abstracto y práctico de las nociones adquiridas, la pureza infantil de la aflicción o de la alegría.

En la penúltima estrofa, el reclamo que escuchamos ("obedientes y sin más remedio..."), si bien nace en el mundo peculiar de la niñez abandonada, puede abarcar entonces toda la "orfandad" del hombre que no sabe nunca el porqué de lo que le sucede. Al empezar la última estrofa, advertimos el estupor del ser que interroga en la sombra y se da cuenta que nadie le va a contestar : los interlocutores no existen, de puro callar se han desvanecido en el silencio y el poema no era en realidad más que un monólogo sin respuesta; los otros niños son tan olvidadizos como las personas mayores. En la tentativa final para no aceptar todavía el abandono como un hecho seguro y definitivo (la duda persiste hasta el último verso), la soledad irremediable del hombre de ahora, presa constante de la obscuridad que lo cerca, se hace más patética por la expresión púdica del dolor y de la queja. La índole radical del sufrimiento no ha variado désde los dramas primitivos de la infancia.

En el poema siguiente Trilce $I V$ el tono es de nuevo totalmente distinto. Como punto de partida, lo mismo que en Tr. $I$, tenemos una sensación, auditiva, pero ahorá crispada, prolongados y rápidamente alucinada; los dos primeros versos, dedicados a traducirla, también rechinan y las palabras (algunas del lenguaje científico, nada poéticas en apariencia, y otras inventadas, como cf. "trifulcas", en una misma nota auditiva) hieren en forma desagradable el oído. El tercer verso sorprende al contrario por su acento directo, hablado y próximo al acento general del poema anterior: de la molestia insoportable causada por el rechinar de las carretas, sólo puede surgir el grito, más bien el quejido, de un niño que castigan por una causa inexplicada. Y, a través de una asociación sentimental espontánea, se introduce el recuerdo amoroso, inspirado por la conciencia oscura de la culpabilidad (es el motivo íntimo de la culpa el que reune el tercer verso con el cuarto), que vemos formarse en el presente caso a partir de la sensación inicial. La evocación de la mujer, designada sin precisión alguna (4) queda estre-

(4) "Aquella otra": el recurrir al pronombre demostrativo de la distancia - cf. más abajo: "aquel no haber descolorado"- es relativamente frecuente en Trilce para indicar to que hay de imperativo y simultáneamente incomprensible en las relaciones del hombre con los seres y con el universo. 
chamente enlazada con ese remordimiento primitivo, incapaz de intelectualizarse, que suscitando inmediatamente un lenguaje propio (en muchos poemas del libro el lenguaje no es dado de antemano): acumulaciones ("duras álgidas pruebas"), suspensiones gráficas ("pruebas....... ...espiritivas"), creaciones de vocablos con resonancia emotiva y a base de elementos preexistentes ("amargurada, espiritivas"). A cada lector le coresponde decidir el valor comunicativo de semejantes asociaciones, que en cualquier momento pueden acarrear la amenaza de una nueva arbitrariedad.

Conviene destacar desde ahora la aporición del lenguaje aritmético que, conjuntamente con el vocabulario temporal, va a ocupar un papel tan importante en el resto del libro : "amargurada por lo uno.... tendíme en son de tercera parte...." (cf. más abajo : "la canción cuadrada en tres silencios"). Todo el drama del amor en Vallejo queda estampado en las relaciones, sólo a primera vista abstractas, entre el uno, el dos y el tres, y el poder pasar de uno a otro : en una confusa aspiración a la unidad, aspiración siempre frustrada, ejemplo del sentimiento de frustración más general que sostiene toda la obra del poeta.

El recuerdo amoroso por lo demás no tiene tiempo de organizarse; se pierde luego en un nuevo desbordamiento de la sensación, de la cual apenas se distinguía : el enlace sintáctico : "mas la tarde...." (5) no indica pues una trabazón lógica ordinaria (ya vimos ejemplos similares en Los Heraldos Negros); anuncia una presencia que se impone por encima de toda tentativa de evocación (el cambio de tiempo,

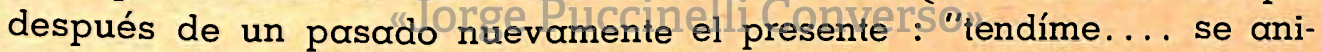
lla...."es característico al respecto), la exclamación del tono familiar - "que la bamos a hhazer" - (6) - subraya lo irremediable de esa presencia y con el empleo de la grafía incorrecta, inspirado al menos por la pronunciación cotidiana ("bamos"), el vocabulario, maltratado por un modo irónico y trágico a la vez, cede, lo mismo que la sintaxis, bajo el peso enorme e incomprensible de todo lo que, fuera de nosotros, coincide en agobiar la existencia humana.

Al poeta sólo le queda la facultad de afirmar "furiosamente" aquella impresión que no puede alejar y, después del amor, la imagen de la madre interviene como un último recurso, inalcanzable. La sen-

(5) Adopto para este fragmento, la versión de la primera edición de Trilce, a mi juicio la única aceptable.

(6) Adviértase una vez más el empleo de una forma hablada, gramaticalmente incorrecta : "qué la bamos a hhazer" ("la" en lugar de "le"); en el mismo poema ya teníamos : nunca las hicimas nada". 
sación presente sofocante, en ia que persiste en forma vaga la figura antes evocada del amor (amor y calor : "nupciales trópicos.... el alejarse rompe a Crisol..." ) y la queja primitiva del hombre ("Lado a lado al destino y llora y llora....") - la sensación pues adquiere intensidad en la afirmación misma, sin nigún control de la conciencia, hasta volverse por poco enloquecedora. Hacia el final ya no tenemos sino unas anotaciones rápidas donde el poema se pierde y se destruye : "Calor. Ovario. Casi transparencia". Los dos últimos versos señalan entonces el sobresalto supremo de la conciencia a punto de ser aniquilada, la cual no logra recuperarse sino como conciencia del doIcr : "Háse llorado todo....". El desorden sintáctico : "háse entero velado..." (cf. en Tr. II el orden desacostumbrado de vocablos : "cuanto heriza nos") colabora al desconcierto definitivo y la palabra última "izquierda" es una palabra dotada en la poesía de Vallejo de una existencia independiente y significativa, cuando el uso diario le atribuye solamente valor de relación; "en plena izquierda" : la "izquierda" se instala por todas partes como el lugar universal del dolor.

En el poema $V$, la obsesión numérica que hace poco señalamos se precisa y revela su más íntima relación con la angustia latente del poeta. Para comprender dicha relación Y el origen de la obsesión aludida, podemos referirnos a un texto revelador de Muro Noroeste, en Escalas Melografiadas. EI autor declara que la justicia no es función humana y no puede serlo y en una página patética nos ofrece las razones de semejante imposibilidad; descubrimos no sólo el substrato de la experiencia personal del poeta, sino también el porqué de algunos de los aspectos más desconcertantes de su forma poética : "El hombre que ignora a qué temperatura, con qué suficiencia acaba un algo y empieza otro algo; que ignora desde qué matiz el bianco ya es blanco y hasta donde; que no sabe ni sabrá jamás qué hora empezamos a vivir, que hora empezamos a morir;... el hombre que ignora a qué hora el 1 acaba de ser 1 y empieza a ser 2, que hasta dentro de la exactitud matemática carece de la inconquistable plenitud de la sabiduría etc....". La palabra que estructura todo el fragmento citado es : "ignora".

En unas páginas agudas sobre el significado de Trilce, Carlos Cueto escribía en 1939 : "La agnosis es el origen de la angustia humana de Vallejo....". (7). Hemos visto el "yo no sé" irradiar en todos

(7) Carlos Cueto : Trilce en la revista Sphintx - julio de 1939. 
los poemas del primer libro de Vallejo y en las composiciones iniciales de Trilce hemos puesto nuevamente de manifiesto la imposibilidad radical de asumir un conocimiento cualquiera, en un poetizar siempre cil nivel de lo humanamente hostil e inexplicable. Pues bien, es notable que, de acuerdo con el texto que acabo de transcribir, tal ignorancia frente $\alpha$ las presencias irrecusables que cercan el cuerpo y la conciencia del niño ( $T r$. III) no se resuelve, sino que al contrario se multiplica cuando choca con las nociones más puras que alimentan la inteligencia en alto grado adulta : "el hombre que hasta dentro de la exactitud matemática, carece de la inconquistable plenitud de la sabiduría". Los números se convierten en nuevas fuerzas misteriosas que comienzan a existir para el poeta como signos de espanto y a llevar una danza inquietante que la inteligencia creadora de las entidades aritméticas no podía sospechar. El paso de la vida a la muerte, del color blanco al color negro, del uno al dos, son igualmente sentidos por Vallejo en la experiencia cotidiana de su propia duración mortal. ¿Cómo el 1 mismo nace del 0 ? El misterio de los límites entre los seres, las cosas, las nocicnes del espacio o del tiempo, ocupa la mente del hombre y las líneas divisorias se separan de los seres, las cosas y las nociones que determinan para vivir con vida autónoma, según un procedimiento ya sensible en algunos poemas de Los Heraldos Negros (Absoluta, Espergesia). El solo hecho de mencionar el nombre de algo existente acarrea de inmediato la aparición de otra palabra complementaria o contradictoria; desde el momento en que el hombre principia a ser consciente $y$ a denominar lo que "percibe, los vocablos mismos empiezan a escapársele y a deslizarse en el "gran colapso".

$\mathrm{El}$ amor (Trilce $\mathrm{V}$ es, en cuanto a la emoción precisa de la que arranca, un poema de amor) participa en la esperanza, nunca realizada, de remontarse al origen y de substraerse a la heterogeneidad esencial que experimentamos en el transcurso diario; los poemas $\alpha$ menudo se contentan con levantar acta de un nuevo fracaso, en una empresa llevada a cabo por las palabras mismas, cuando el poeta las proyecta unc, tras otra, sin poder muchas veces organizarlas - dialéctica vital del simple y del doble, del ser y del contrario del ser. De ahí la extraordinaria pobreza de imágenes, en el sentido que dan al vocablo los creacionistas o los surrealistas contemporáneos,y, en cambio, la importancia del vocabulario abstracto cuyos términos opuestos se suscitan e informan en función constante de reciprocidad, sin lograr nunca resolverse.

El "grupo dicotiledón" de pronto invocado en el primer verso de Tr. $V$ encierra la intuición amorosa en el símbolo matemático general 
de cuanto existe en forma de "dos" : el amor se revela en la perfección aparente del grupo. Pero simultáneamente en el "dos" existen ya las "propensiones de trinidad" (8) (en el cumor la posibilidad del hijo), en la plenitud de ser una invasión de "heterogeneidad". "Finales que comienzam, ohs de ayes" : aquí están los vocablos lógicos irreconciliables, liberados de las relaciones usuales y confrontados en su modo de existir particular, hasta afirmar la imposible identidad de los contrarios, la única en poder resolver la angustia de la división. La afirmación inicial reaparece más imperiosa aún, como la instancia del poeta a las cosas, a un "aquello" impreciso que representa todo lo que es, en trance de resolución por el amor - instancia para detener el curso devorador de las metamorfosis ("Aquella sea sin ser más") y para fijar el éxtasis unitario, fuera del tiempo, del cambiar constante y de las contingencias de lo sensible ("y piense en son de no ser escuchado/ y crome y no sea visto") - instancia ya perdida en cuanto se la formula, puesto que la voz misma, no bien se pone a hablar, a designar y a nombrar, inaugura el pasar infinito de lo uno a lo otro.

La exhortación : "Los novios sean novios en eternidad" recuerda más precisamente el fondo emotivo del poema, sin que la fijación del amor en un momento privilegiado de pureza extratemporal no pase de ser un deseo urgente mas imposible de llevar a los hechos. El sentimiento angustiado del tiempo, en que todo es pasaje y todo pasaje una agonía, se lleva el poema entero. El "pues" ques encabeza el siguiente verso no introduce una conclusión sino que señala una nueva instancia, ya desesperada, puesto que, más allá propiamente de los novios, en un sentido mucho más general, la sola mención del primer guarismo de la serie indefinida de los números, el l, amenaza con engendrar el lenguaje entero sin que sea posible en adelante detenerlo; del nacer nace siempre el nacer; del silencio mismo, del $O$, de lo homogéneo termina surgiendo, como un exceso de ser, el $1, y$ trás él nuevamente el sinfín del lenguaje : no existe pues escapatoria. El último verso que reitera las palabras iniciales, subrayando su contenido amoroso : "Ah grupo bicardíaco" es un grito de derrota y de zozobra irremisible. "Al final, el poema de Trilce in-concluye en una irresolución" ( $(9)$ : el final de Tr. $V$ es característico; el poema, organizado de antemano, se ha ido

(8) La palabra "petreles", al principio del segundo verso, indica en esta poe. sia abierta a solicitaciones diversas, un residuo de visión, la cosecha de una mirada al mundo exterior; además el abrir de alas del ave marina representa todas las "oberturas". el nacimiento de las nuevas cosas y los nuevos seres.

(9) C. Cueto : artículo citado. 
desarrollando, a partir de la expresión.inicial, por golpes de intuiciones irrevocables e invocaciones ineficaces : "A ver... A ver... y no glise... Pues no deis.... Y no deis....", sin que el poeta dirija o domine la ordenación. Al terminar nos encontramos solamente con la intuición del principio, tan poco fundamentada y en cambio gravada con ioda la angustia acumulada en el intervalo.

Los cinco primeros poemas de Trilce nos han ofrecido ejemplos variados de la escritura poética de Vallejo. Todos revelan sin embargo una sola actitud fundamental, la misma que, a lo largo de Los Heraldos Negros, se venían precisando poco a poco, conforme se iba liberando de las influencias culturales anteriores - actitud que separa a Vallejo de los poetas solicitados por la embriaguez de las imágenes en el umbral común del sueño y de la vigilia, de aquellos igualmente que tratan de rivalizar con lo creado y de suscitar un universo nuevo actitud del hombre situado en el "ahora" (la palabra : "ahora" es una de las que a menudo aparecen en el libro) y que se encara, desde niño ( ¿donde estó, pues, el niño, que abre sus sentidos hacia el mundo y descubre maravillado los colores y los sonidos?), con las fuerzas oscuras de las cosas y de los seres, al acecho de ese algo hostil que cualquier sensación manifiestä ("que le vamos d hacer"). Los poemas de Trilce no conducen a ninguna parte $\mathrm{y}$ continuamente reciben cargas de incognoscible. Toda aprehensión, foda detención definitiva se revela imposible, y asimismo toda conclusión. De ahí un constante arrancar y pararse, con la reaparición de la afirmación original, a veces lancinante, que equivale a lo que en otros poetas sería el desarrollo constructivo del poema.

Privados de los recursos de la inteligencia, estamos siempre en la hora en que surge la primera pregunta frente al misterio terrible de lo indeterminado (el calor del medio día en Tr. II o el rechinar de las carretas en Tr. IV son ejemplos de cuanto "nos eriza" sin que hayamos dado motivo para ello). Tenemos que insistir en ese carácter "in-inteligible" de la poesía de Trilce que busca "al tanteo en la oscuridad". sin llegar a ver o a organizar la sensación confusa. Ha sido definitivamente eliminada toda clase de seducción estética y muchos poemas tienen un aspecto incoherente, al menos entrecortado; una opacidad dolorosa determina los medios de expresión aparentemente más opuestos, pero por ella secretamente enlazados : lenguaje apenas aprendido que copia en la forma más humilde las alternativas de una congoja 
infantil ante las tinieblas, el abandono y el hambre (Tr. III): lenguaje a su vez creador de obsesión por la virtud implacable de ciertos voccblos (Tr. II), o lenguaje que se encrespa furiosamente con la sensación (Tr. IV), se deshace y rehace, al margen de la sintaxis y hasta de las formas acostumbradas, se contrae y de pronto se afirma paradójicamente en la viclencia destructora de los contrastes (Tr.V), cuando los "finales" engendran los "comienzos", la plenitud del 0 , el principio del $1 \mathrm{y}$ el exceso de silencio, la voz, en una tentativa pars no ceder a la atracción del vacio, de aquellos "abismos espeluznantes" que el mismo Vallejo recordaba después de la publicación de Trilce.

Bien vemos entonces, los peligros a los que los poemas hacen frente de la primera a la última página del libro - peligros también contradictorios y sin embargo pendientes de la misma causa profunda: a partir de la extrema humildad, cuando la intensidad de la emoción no sostiene en forma adecuada al lenguaje, existe el riesgo de caer en un prosaísmo deliberado; cuando al contrario, los vocablos de por sí adquieren una influencia exagerada, pueden suscitar un nuevo tipo de retórica; finalmente el desmantelamiento total del lenguaje nos llevaría a una incoherencia yerdadera, ya imposible de justificar.

\section{III.- LOS TEMAS LIRICOS : LA INIÑEZ, LA MADRE, LA CARCEL, EL AMOR}

Repetidas veces encontramos en tal o cual poema de Trilce versos que parecen como supervifencias delaVepoca' modernista : "Cuando la calle está ojerosa de puertas..." leemos por ejemplo en $T r$. VII - imagen con antecedentes en los más antiguos poemas de Los Heraldos Negros (cf. Hojas de Ebano) y de procedencia netamente herreriana. El primer verso de Tr. XXIX : "Zumba el tedio enfrascado...." tiene una resonancia idéntica. Cuando Vallejo acepta todavía organizar aiguna que otra metáfora (cada día con menos frecuencia), siempre vemos introducirse nuevamente los primeros recuerdos de su iniciación literaria. Pero lo importante es que ahora dichos recuerdos se presentan solamente en forma episódica, y el único poema de Trilce que posee casi todos los caracteres de un cuadro simbolista armonioso (1) es Trilce XXIV (2), aunque la última palabra : "Lunes", se diría

(s) En cuanto al empleo de la palabra : "ñandú", es otra muestra de aquella localización de los motivos modernistis que hemos estudiado en Los Heraldos Negros.

(2) Lis referencias evangélicas que en él se encuentran, pertenecen a la vieja corriente poética. El simbolismo bíblico tradicional, es generalmente abandonado en los otros pecmas de Trilce. En Pocmas Humanas, en camhio, Vallejo manifestará espontáneamente el áiento profético de la Biblia, fuera de toda influencia literaria anterior. 
que arbitrariamente separada del contexto, confiere a los versos una nota de in-conclusión característica.

En los otros poemas se dan, a veces puras, a veces coordinadas - enlazadas, las diferentes tendencias de la expresión poética que hemos intentado analizar en las composiciones iniciales del libro.

La incapacidad de Vallejo para apartarse del dolor cotidiano va íntimamente unida a una experiencia personal del tiempo que hemos seguido a lo largo de Los Heraldos Negros, especialmente en los poemas relacionados con la niñez. Tr. III nos ha dejado oír a un niño que se dirige directamente a otros niños : Trilce $L I$ nos ofrece un ejemplo, si cabe, más perfecto todavía de la misma modalidad. Al iniciarse el poema no hay nada que prepare al lector : los versos apenas están escritos para un lector. Un niño habla a media voz a otro niño que está llorando $\mathrm{y}$, si bien el ritmo adquiere mayor amplitud en la tercera estrofa (a partir de : "A mi, que había tanto atisbado...."), son las pausas, las repeticiones, las palabras más bien murmuradas que verdaderamente pronunciadas, y sobre todo los silencios que ocultan más de lo que las palabras denuncian, son las súplicas y las amenazas, más tiernas aún que las explicaciones, son todos aquellos síntomas de una lógica preadulta, urgente y desesperada, los que dan $\alpha$ un poema, despojado de adomo inútil, el tono excepcional de dulzura, irremediablemente desgarradá. Pues aquí tampoco nada termina, nada concluye y la conciencia infantil, que está despertando al sentimiento irremisible de la propia culpabilidad, al mismo tiempo que tropieza con todos los obstáculos de la comunicación entre los seres, nunca había sido en esa forma presentada por Vallejo, con una intensidad de emoción casi animal, cuando el lenguaje es llanto todavía, signo de aflicción mucho más que función de elocución. (3).

En el poema siguiente - Trilce LII - tampoco tenemos un recuerdo de infancia, sino la infancia misma, rediviva en la confidencia del poeta niño a uno de sus hermanos o hermanas, - no una vuelta hacia algo pasado, sino, en el presente de nuevo realizado de la infan-

(3) Tono semejante aparece de pronto en medio de tal o cual poema de expresión por lo demás sencilla : cf. p. ej. Tr. $X L$ :

'y aun lo que nos habríamos enojado y peleado

$y$ amistado otra vez

$y$ otra vez......". 
cia, una tentativa para salvar, proyectándolo sobre el futuro (cf. Canciones de Hogar y en primer lugar Enereida), aquello que el hombre que actualmente escribe percibe, a pesar de todo, como ausencia. Apenas necesitamos señalar las expresiones familiares (tomar el pelo, apanuscar), los fragmentos hablados tras los cuales es fácil imaginar un movimiento o una sonrisa de complicidad ("iy no me vayas a hacer cosas!") - el poema todo es un fragmento de conversación (desde el primer verso : "Y nos levantaremos....").

El tono difiere sin embargo del poema anterior, porque la niñez aparece ahora como arropada, protegida y resguardada contra los misterios exteriores por la acumulación de los detalles de la vida cotidiana, ausentes al contrario de Tr. LI. Lo mismo que en Enereida todo es redimido al calor de las cosas buenas, favorables, y al amparo de la madre que organiza en torno de los niños una capa de dulzura y bie. nestar. Si bien el poeta deja al niño de otrora exprescrse como en sus años serranos, éste, profundamente conmovido, encuentra $\alpha$ lo largo del poema las palabras más significativas creadoras de aimósfera : "mamá toda claror, cantora cólera, almuerzo musical (las crea también cuando le hacen falta : (tus huecos onfalóideos") y otras que mutuamente se atraen en un redoblamiento del efecto sentimental : "las cometas azulinas, azulantes". La elección acertada de los vocablos sugiere la impresión de ternura humilde y por una vez feliz, que todo lo humaniza ("el are nenet') yacude aloscobjetos para liberar su alma entonces benéfica. La unidod declas estrofas entre sí no se debe a la progresión tradicional de un relato sino a las solicitaciones suco. sivas del sentimiento ("Otro día querrás.... O querrás.... Y llegas .... $Y$ en el almuerzo..."). Cierto humorismo aflora al terminar y nos abre "las puertas del taller" (4), explicánclonos, de un modo que algunos lectores juzgarán prosáicos, el origen de ciertas deformaciones ortográficas, sistemáticas en Trilce ("buenos con b de baldío, etc....": las letras mismas pueden recibir vida independiente : "la $\mathrm{v} /$ dentilabial que vela en él"). En la sombra de la madre - fuerza propicia que compensa todas las fuerzas adversas (el hogar, que prolonga la madre, es de por sí el único contrapeso a la hostilidad original del mundo). en la seguridad de la comida siempre proporcionada por la madre, el hambre es experimentado constantemente como el ejemplo de la impotencia del hombre frente al misterio circundante y es notable el pres-

(4) Expresión de Amado Alonso en su libro sobre Neruda (p. 32), respecto a una particularidad por lo demás completamente diferente. 
tigio, subrayado por la versificación, que adquiere una palabra como "manteca" en la última estrofa. En el detalle de los versos, los vocablos inician sus encuentros autónomos, característicos de otros poemas: en la tercera estrofa por ejemplo la disposición de las líneas destaca la novedad de esías asociaciones idiomáticas.

Desde el principio, el empleo del futuro de los verbos tiende a asegurar la perennidad del universo familiar, el único enteramente humanizado, universo sin memoria. universo siempre actual y preservado a fuerza de afirmación : en la última estrofa el presente varbal se substituye normalmente al futuro. Pero en ese presente mismo ya no hay igualdad entre aquel que habla y el supuesto interlocutor : el primero parece que mirara un poco desde fuera; el lector presiente confusamente que la voz del que habla es una voz solitaria, a la cual ninguna otra, aquí tampoco, responde - una voz que hasta en el poema que consideramos perora en el vacío y no recibe eco.

La visión de un tiempo sin momentos separados, sucesivos, es fundamentalmente distinta de la visión temporal de la mayoría de los poetas anteriores o contemporáneos. Por ejemplo el "saber soñar", el "hacer soñar" de Antonio Machado, poeta predilecto de la temporalidad fugitiva no tiene relación alguna con la poesía de Vallejo. "De toda la memoria, sólo vale, el don preclaro de evocar los sueños" : Machado siente el pasado como perdido y la facultad de soñar, al evocar nuevamente el pasado permite recuperar su imagen y en cierta íorma su esencia, lo que habia de permanente en cada instante fugitivorecuperación nostálgieă pero en ningún momento trágica o desgarradora, más bien al contrario consoladora. Para Vallejo en cambio el tiempo no se acumula y el presente no se enriquece con la experiencia del pasado : en cualquier instante, la totalidad del yo, es arriesgada en el presente. Los poemas en que el lenguaje infantil aparece sin transposición alguna, constituyen el caso límite. Los que tienen como tema de inspiración el retorno a la casa natal, después de mueria la madre, manifiestan asimismo esta dimensión temporal propia de la poesía de Vallejo.

En Trilce LXI es fácil seguir los vaivenes de una conciencia semilúcida : el poeta indica los movimientos de su cuerpo; son movimientos maquinales; el que habla ve las cosas en medio de una somnolencia opaca, dolorosa; los recuerdos surgen por un momento ("El poyo en que mamá alumbró...."), tratando de perpetuarse en el presente ("Ha 
de velar papá rezando..."”) o mezclándose con la visión actual inmediatamente subjetivada ("Dios en la paz foránea....") y el poema termina hundiéndose en un sueño que confunde todas las cosas. A la hora de hundirse igualmente, el hombre sigue hablando, mecido por el paso del animal, de obsesión en obsesión ("Todos están durmiendo para siempre") y de indiferencia en indiferencia, como quien se va durmiendo después de un largo caminar ("dice/ que está bien, que todo está muy bien") : todo se resuelve en una sensación imprecisa y ambigua de bien y malestar).

Nuevamente con Enereida podríamos cotejar Trilce LXV.

"Madre, me voy mañana a Santiago,

a mojarme en tu bendición y en tu lianto ...." :

el procedimiento, casi sistemático a partir de la segunda línea, que consiste en concretizar lo abstracto para conseguir una intensidad máxima ("acomodando estoy mis desengaños...... estoy cribando mis cariños... tu arco de asombro, las ... columnas de tus ansias... etc.") no es nuevo, pero su frecuencia aquí no deja de ser notable; amplía la visión y la sitúa en una altura serena que prepara la segunda parte del poema. Paralelamente los objetos usuales se animan con vida patriarcal y el humorismo que preside a su evocación ("Me esperará mi sillón ayo.... rezongando a las nalgas tataranietas...") pertenece a ese clima de dicha familiar que la presencia de las cosas garantiza a la infancia (el adjetivo "quijarudo" es creado en el cuadro de esta evocación, tierno hasta lo grotesco, cuando el poeta empieza a aceptar las puras solicitaciones verbales : "de correa a correhuela....", cf. más abajo : "para todas las cintas más distantes/ para todas las citas más distintas").

La primera estrofa del poema se enlaza directamente con la tercera, por encima de la segunda; esta última presenta una unidad masiva (subrayada por el movimiento inicial : "Me esperará....", que se repite dos veces a mitad de verso) y está escrita en futuro, tiempo que ya hemos visto aplicado a los objetos felices del recuerdo para perpetuarlos en ese forma, solos, contra la realidad de la muerte; por cierto el futuro aquí empleado es un falso futuro, un futuro hipotético, pero no lo sabemos antes de que se presente de nuevo, al iniciarse la estrofa 3 , (5) el presente, del cual, al extremarse el sentimiento, surge de pronto,

(5) El verso : "Estoy plasmando tu fórmula de amor....." reitera una expresión casi idéntica de Para el alma imposible de mi amada en Los Heraldos Negros:

"Y si no has querido plasmarte jamás

en mi metafísica emoción de amor.....". 
como en algunos poemas de Los Heraldos Negros, la aspiración hacia la unidad.

Desde el principio de la cuarta estrofa : "Así muerta inmortal....", el tono es otro y la segunda mitad de la composición se organiza a partir de una "mutilación sintáctica", parecida a las señaladas por Ämado Alonso en la poesía de Neruda. A la palabra "Así...." no corresponde ningún término de comparación, ningún "como....". "Asi" aparece como una revelación brusca que no procede lógicamente, sino que marca un "salto" - todopoderoso, si bien incompletamente justificado - de la intuición, la cual no tiene en cuenta la sintaxis. Hasta el final no nos libraremos del "Asi" que vanamente el poeta trata de dilucidar por completo antes de repetirlo como un eco que va degradándose (Enereida concluía por un movimiento de igual índole intuitiva pero ascendente : tenemos ahora un movimiento descendente). La conexión con la primera parte es asegurada por expresiones como : "los arcos de tu sangre" (en la primera parte : "tu arco de asombro"), "la columnata de tus huesos" (id.: "las columnas de tus ansias"), pero el grito "muerta inmortal" resulta imprevisto: hasta el momento el poeta parecía dirigirse a una persona viva; al darla ahora por muerta la salva sin embargo inmediatamente de la muerte y del tiempo; la angustia del huérfano se resuelve en su deseo de perpetuar la infancia que ha ido perdiendo mientras tanto : el tiempo estalla en eternidad y la madre, muerta porque inmortal, inmortal porque muerta, se convierte en un símbolo inmenso, ilimitado, a cuya sombra todo se cobija y adelgaza ("mi padre... el primer "pequeño que tuviste") (6) (en la tentativa, actualmente victoriosa, por eternizar el bienestar del hogar. Ya anunciado en Enereida, encontramos el tono profético que alcanzará una expresión múltiple en los últimos poemas de Vallejo.

Ocurre, pues, que el sentimiento agónico del tiempo deja la infancia, en lo que tiene de seguro, proyectarse en un presente inmortal; mas la dicha infantil en realidad ha sido perdida por el hombre y generalmente el proyecto de recuperación fracasa a pesar de lo intensamente sugestivo de la evccación; la infancia sigue existiendo pero como una herida siempre abierta en el hoy: examinemos por ejemplo Tr. XXIII y Tr. XXVIII.

En Trilce XXIII la elección de vocablos y construcciones poco usados o arcaicos ("tahona estuosa de aquellos mis bizcochos...") que

(6) Habría que cotejar con la prosa El Buen Sentido en Poemas Humanos, donde tendremos la temática opuesta, llegando el poeta a escribir: "La mujer de mi padre está enamorada de mi...". 
dilatan más aun lo majestuoso de la invocación inicial, contribuye de inmediato a colocar a la madre en un plano casi mítico - y con la madre todo lo referente al pan y a la comida: los términos característicos se acumulan en los primeros versos (7) : "tahona, bizcochos, yema, mendigos" (parece que igualmente "gorgas") y la expresión : "hos. tias de tiempo" los prolonga en un resumen significativo (cf. más abajo una imagen común que adquiere una intensa calidad emotiva : "tus puros huesos estarán harina...") Después de las invocaciones iniciales que dan a la madre categoría de símbolo, volvemos a la evocación más precisa del universo de la niñez - evocación hecha en el pasado verbal, pero que se tuerce de pronto cuando la palabra "ahora" (8) invade el poema. Tenemos entonces una nueva multiplicación del símbolo, pero ya oprimido por el dolor actual : al desmoronarse el mundo de la madre y del pan cotidiano, el huérfano queda desamparado en las tinieblas exteriores, las cuales, en relación con la nota dominante de los versos, tienen la forma de una gran mandíbula hostil y omnipresente.

"Tal...", palabra inicial de la última estrofa, es una de aquellas palabras que no determinan ninguna decisión lógica sino que introducen una nueva perspectiva sentimental (9); al terminar el poema en la efusión patética de la congoja infantil, el futuro y el presente se superponen una vez más ("Y nos lo cobran cuando, siendo nosotros, pequeños entonces"). La exigencia implacable, que-su misma impersonalidad ("nos van cobrando... nos lo cobran) vuelve más temible, subraya, como nunca hasta la fecha, el sentimiento omnipoiente de la orfandad que incide en tantos poemas de Vallejo; la vida nos es dada sin recurso o defensa y la obsesión del hambre siempre mantiene la expresión poética al nivel de las obsesiones elementales, del instinto de vida y de la presencia incontrovertible de la muerte. El último quejido no es más que el balbuceo de la carne abandonada: "¿dí, mamá?".

A lo largo de Trilce XXVIII, la entronización de los antiguos elementos del hogar en el presente es tal vez más sensible aún. La palabra

(7) Las imágenes no se desarrollan sino que también se acumulan, relacionadas con la intuición centrati y sin prencuparse por la coherencia objetiva - hecho que separa la poesia contemporánea de la simbolista y anterior al simbolismo.

(8) En ese momento, a partir de la palabra temporal, se da una asociación puramente verbal, tal como existen en los poemas de Trilce sin tema lírico evidente.

(9) Cada estrofa tiene en esa forma su unidad propia (a falta de otro nombre seguimos llamando estrofa los conjuntos de versos entre dos espacios blancos), la cual no depende principalmente de la estrofa anterior sino de aqudi nuevo ímpetu, en parte arhitrario de un punto de vista lógico, que la provaca. 
"MADRE", destacada en mayúsculas, cobra su valor definitivo: el poeta no medita sobre la ternura maternal (que se confunde de nuevo con la ternura alimenticia); experimenta actualmente su realidad como algo ausente, recurso único pero inaccesible. Los fragmentos de humorismo tiemo (el "bisbisear" de las ancianas indicado en la sonoridad del verso) confieren al sentimiento de la ausencia infranqueable un carácter púdico, constante en la poesía vallejiana, no por eso menos desesperado. (10).

Trilce LVIII, el más hermoso de los poemas de la córcel reunidos en Trilce, recoge asimismo el recuerdo de la niñez y de la madre (Cf. Alféizar en Escalas Melografiadas). Como punto de partida tenemos una sensación general de prisionero: "En la celda, en lo sólido...", la que pronto se intensifica hasta la pura alucinación y empieza a confundir las cosas y los seres ("los rincones" son la materialización dramática de todos los límites que encierran al hombre, y también participan simultáneamente de dos realidades: los dos lados, las dos paredes; rompen a vivir con igual intensidad que los presos acurrucados, de los cuales pronto no se diferencion).

Desde el primer verso, el poema pierde la conciencia clara del mundo circundante; en un estado de modorra con pesadillas (cf. Tr. LXI), el poeta deja las palabras agolparse ("se ajan, se doblan, se harapan") o convocarse "mutuamente a distancia (como una ilación en la lógica absurda del sueño, tenemos el primer verso: "En la celda, en lo sólido..." que reaparece más abajo, sensiblemente modificado: "en la celda, en lo líquido..." y hacia el final: "en la celda, en el gas ilimitado..."; las nociones generalmente unidas por el lenguaje : sólido, líquido, gas, vienen a orientar el delirio verbal), mientras que el pasado $y$ el presente se enlazan estrechamente (en la estrofa que empieza: "Apéome del caballo..." vemos introducirse el tema de Tr. LXI) y el masticar del compañero de cárcel es experimentado como algo ajeno y asimismo como sensación propia; la infancia invade el presente donde retumba el eco de una conversación ("No creas..."), infancia de pron. to asumida por todos los momentos del tiempo a la vez.

Del sentimiento de desolación y abandono que regía el monólogo

(ro) En Trilce $X L V T$, paema de factura casi regular (un soneto en endecasílabos, con rimas inclusive en los dos cuartetos), el tema es el mismo : ausencia de la madre en la comida. 
de sonámbulo, surge entonces, como otrora en EI Pan Nuestro, el sentimiento irreflexivo e irremisible de la propia culpabilidad $\mathrm{y}$, marcados ayer y hoy conjuntamente por el signo de lo irremediable, el futuro es suscitado como el tiempo de la reparación, mas un futuro en el cual el pasado ha de repetirse tal cual: la infancia es simultáneamente pasada y futura, culpable en el pasado, buena en el futuro; el poeta se portará mejor mañana, en su niñez que hace tiempo que no existe $\mathrm{y}$, cuando escribe: "Ya no reiré...", no es un preso el que habla sino, como en Tr. LI, un niño que trata de hacerse perdonar. Todas las dimensiones del tiempo se superponen en la fuerza primitiva de un remordimiento intrazmisible. Vallejo no toma distancia aguna consigo mismo, con lo que fué y con lo que será. En el último verso hay como un llamado del mundo exterior, que tan sólo sirve para prolongar el dolor en la incertidumbre de la pregunta : "¿quién?" (f. Tr. I) : "¿quién tropieza por afuera?".

En Trilce XVIII, a partir de la misma sensación alucinadora de los murcs de la cárcel se introduce nuevamente la imagen de la madre que se troca en símbolo innumerable (la madre es la que libera, la que abre las puertas de todas las celdas de la vida), pero aquí la visión inquietante cuaja más precisamente en un número : el cuatro, que empieza a tener un valor de obsesión, determinante en el desarrollo del poema. (11). Las paredes, la madre y la noche terminan confundiendo sus nocicnes hasta provocar, hacia el final, como una danza absurda de gestos y guarismos, que sella la soledad, carenie de todo recurso, del poeta : este yar no se contenta con Yepefir" el "yo no sé" sordo y sin repuesta; entrechocando los vocablos que se atraen y al mismo tiempo se niegan mutuamente, va creando un ademán imposible de representar ("en busca de terciario brazo"'") y cuyos elementos no aparecen sino para destruirse en el acto, y destacar, en violento contraste. la afirmación inequívoca de la orfandad: "esta mayoría inválida de hombre".

En el poema del carcelero (Trilce $L$ ), el sufrimiento se oculta bajo el tono irónico de los versos: tenemos un relato sin perspectiva más allá

(ir) La obsesión numérica se explica en este caso de modo inmediato: el 4 es cl número perfecto, infranqueable, que limita el universo del preso : "cuatro paredes... cuatro rincones..." (cf. los cuentos de Cunciformes). Lo encontramos de nuevo en los otros poemas de Trilce, inspirados por la cárcel : "El cancerbero cuatro veces al día maneja su candado..." ( $T r, L)$; los jueces que juzgarán ai detenido por lo mismo serán probablemente cuatro: "Es posible me persigan liasta cuatro magistrados...."; y el mismo número invade igualmente el recuerdo de la niñez en él poema anteriormente estudiado ( $T r, L V I I I)$ : "cuando mi madre reza. . t. a las cuatro de la madrugada....". 
del presente, pero la composición escapa de los peligros de la prosa por el humorismo rebosante de temura que humaniza hasta las cosas más humildes ("los fundillos lelos melancólicos"), mezcla las sensaciones interna y externas ("abriéndonos, cerrándonos los esternones... - juega el viejo... a lo ancho de las aortas...") y disimula el dolor ("como nos duele esto") tras las apariencias de una objetividad medio burlona ("pero siempre cumpliendo su deber").

El humorismo tierno también salva Trilce XLI (contabilidad de las costillas y de los músculos, nacimiento paradójico de la risa en medio del dolor, dislocación final a base de onomatopeya), poema en el cual se nos presenta, directamente expresada, una sensación dolorosa (de golpes recibidos).

Trilce XXII es más complejo, más incierto: la evocación inicial del proceso (más bien que de la córcel) se pierde en una larga afirmación con raíz amorosa, pero algunos detalles: el "cuarto" con caracteres de obsesión como en la celda, el hombre simbolizado por sus "esquinas" (12), la amenaza de ser nuevamente capturado ("vuelto"), nuevamente juzgado, como otro hombre, por una culpa que él no ha cometido ("que me juzgen pedro"), la ironía familiar con que se exorcisa semejante posibilidad ("bien hecho") - todo deja suponer que el poema fué escrito poco tiempo después de la liberación. Una sensación de bienestar, en el instante ("Ahora que chirapa tan bonito...") una vez más eternizado ("chirapado eterno y todo") dirige la simple afirmación de una presencia, la propia, - una presencia abierta hacia otro ser, la amante, y por ella, hacia un sinfín de ternura-er una presencia que tan sólo es, sin resolver el misterio de su origen ("aquí me tienes, de quien yo penda"), es y repite obstinadamente que es (hasta la última palabra : "Heme!"). Este tipo de afirmación ineficaz se ha substituído a la reflexión o a la meditación : el "yo no sé" nunca concluye.

El amor en la poesía de Vallejo no presenta la diversidad de niveles y de modos que, ya lo advertimos, Pedro Salinas ha analizado en la poesía de Darío: en algunos poemas de Los Heraldos Negros hemos visto el "sentimiento" amoroso vestirse de imágenes modemistas y aceptar un simbolismo trascendente de prosapia netamente literaria; Vallejo ha descartado rápidamente esta herencia sensible en sus primeras o-

(12) Cf.: "en las cien esquinas de esta suerte" ( $T r . X X X I)$. 
bras; en Trilce, el amor está libre de toda contaminación sentimental, lo mismo que de toda prolongación lírica que excedería los límites de la experiencia inmediata: experiencia del abandono o del consuelo, de las faltas o de las satisfacciones del vivir cotidiano.

La relación de un amor pasado que leemos en Trilce XXXVII resulta en exceso anecdótica y por lo tanto mediocre, pero da la pauta de una poesía de las alegrías y de los sufrimientos siempre ajustadas a las alegrías y a los sufrimientos del niño de otrora.

Trilce XI, que evoca igualmente un amor pasado, presenta para nosotros mayor interés: el amor desaparecido reaparece en el presente Y simultáneamente sigue experimentado como ausencia. Los tiempos verbales intrincados y las reiteraciones obstinadas ( $M e$ he casado... Se ha casado...") frente a lo que fué, como si ello no fuera aún definitivo ("pero todo de engaños, de candor como fué") contribuyen a crear la incertidumbre y relacionar el amor, en forma caracteristi$\mathrm{ca}$, con las primeras realizaciones de la infancia : el amor casi siempre es afirmado en su inocencia e impotencia originales - sensación confusa más que sentimiento - tentativa para prolongar o constituir de nuevo el mundo privilegiado del hogar materno (la amante hace el papel que en otros tiempos la madre: envuelve al hombre con un calor animal que lo separa de la hostilidad del mundo circundante).

Desde ese punto de vista habremos de considerar algunos poemas que por lo demás no óstentan calidades deprimes orden, ya que el lenguaje de la ternura familiar puede caer en lo trivial de la mera anécdota. En Trilce XXXIV Ia repetición como de un toque fúnebre y al principio de cada estrofa de: "Se acabó..." (y a fines de verso la repetición secundaria de una palabra de tonalidad también mortuaria: "tarde"), el amor resumido en "el diminutivo" con que los amantes se reconocen, la dulzura especial del lenguaje ("parla y parla... bueno lo malo..."), el desdoblamiento del primer verso (se acabó el extraño ...": el "extraño" es el poeta mismo - cf.: La voz del Espejo" - L.H.N. - donde el poeta iba "rezongando" su propia marcha funeral) dan una expresión familiar a lo trágico de un abandono definitivo; el modesto universo de la ternura, única defensa contra la soledad del mundo exterior, se ha derrumbado una vez más; el verso: "mi mayoría en el dolor sin fin..." termina reafirmando "esta mayoría inválida de hombre" que veíamos reinvindicada al final de Tr. XVIII.

Después de muerto, el amor persiste en las cosas más cercanas y humildes. Trilce $X V$ presenta el tema de la visita a los lugares anteriormente testigos de un amor por ahora difunto. El poeta está separado de su propio pasado tanto como de la mujer amada (lo que él expresa 
por medio de una redundancia expresiva, si bien gramaticalmente incorrecta: "ya lejos de ambos dos..."). Son suficientemente conocidas las grandes composiciones con participación de la naturaleza que el mismo tema inspirara a los románticos del mundo entero: nada parecido tenemos en Vallejo - sino más bien un poema íntimo en el "rincón" de una habitación pobre cualquiera - poema que vale únicamente por el hablar apagado de la voz que nos oculta más de lo que nos revela ("En el rincón aquel...") y actualiza la queja, dejando que la presencia inmediata de la amante perdida invada la evocación del pasado ("Has venido temprano a otros asuntos... No lo equivoques. . ."), mientras que en el campo formal, una adjetivación un tanto osada ("poca y harta y pálida") con antecedentes en Los Heraldos Negros (cf. Los Pasos Lejanos), un enlace verbal lógicamente absurdo y sin embargo bruscamente revelador ("me he sentado a caminar": "sentado" en un presente sin salida, el poeta camina hacia lo que fué, o mejor dicho espera que los recuerdos empiecen a caminar hacia el momento actual para inmiscuirse en el "ahora"), la derrota progresiva de la organización poética que va cediendo ante la emoción totalitaria (la primera estrofa es regular: versos alternados de 13 y 11 sílabas, rimas; en la segunda las rimas son ya imperfectas y el ritmo del endecasílabo predomina sin imponerse) - todo lo dicho confiere a un poema que no es de los mejores un carácter sin embargo netamente vallejiono.

La estrecha conexión delas pobres cosas y los pobres lugares con el amor y la amada puede concluir en una asimilación completa. En Trilce LXXII ningún ser humano aparece concretamente: el poeta habla con el "salón" mismo, el cual en realidad reune todas las características del ser amado ("aunque te quise, tu lo sabes... ya ni he de violentarte a que me seas de para nunca..."); paralelamente, el hombre que recuerda lo pasado tropieza siempre con lo que es o ha sido en forma irremediable, sin causa ni pretexto, y renuncia $\alpha$ encontrar explicación, perseguido, como en la celda, por los números que concretan su angustia sin ofrecerle ninguna solución ("salón de cuatro entradas $\mathrm{y}$ sin una salida... te hablo por tus seis dialectos enteros... (13) Julio estaba entonces de nueve...").

(13) Podemos ver en este ejemplo cómo nace una de aquellas asociaciones verbales que generalmente no nos revelan su secreto y se pierden en una incoherencia a veces exagerada : la sensación, en Trilce, no tiene nunca valor representativo, sino qué iibera una carga afectiva violenta y trastornadora; en el presente caso la sensación del "salón" del recuerdo, como una nueva celda para el hombre, queda fijada en las paredes (las 4 laterales, el techo y è piso) que limitan el horizonte, y más especialménte en -él 
En Trilce LXII, la invocación a la mujer perdida, nace igualmente al amparo de las cosas (véase asimismo Tr. XLIX) : "Alfombra... Corteza... Almohada...", otras tantas palabras por lo demás que, al comienzo de las estrofas, simbolizan las cualidades de la mujer. Un tono permanente de confidencia a media voz ("Cuando vayas al cuarto que tu sabes..." - cf. Tr. XV: "en el rincón aquel...") t anspone en el futuro, por la permanencia de las cosas, una aventura humana ya pasada: el tema del amor más allá de la tumba y un simbolismo tradicional persistente (compárese : "en las siete caídas de esa cuesta infinita..." con las imágenes de Nervazón de Angustia en Los Heraldos Negros) resultan completamente renovados por el ritmo p.opio de los versos que deben su carácter patético a los ritmos ordinarios del habla afectiva ("iQuién sabe! /Oh no. Quién sabe... como antaño, /como antaño..."), penetrando de humanidad cuanto existe alredecior ("en la esquina de los novios ponientes de la tierra...). (14).

La conciencia que entonces se manifiesta no está nunca totalmente despierta: en todos aquellos poemas de Vallejo donde tan fácilmente se confunden los lugares, los tiempos, las cosas y los seres encontramos una lucidez lógica atenuada, cuando no borrada, - consecuencia de un estado intermedio entre el sueño y la vigilia (el hecho era visible más que todo en Tr. LXI Y Tr. LVIII) : en Trilce XLII, imágenes delirantes guían el curso del poema, mediante las repeticiones ("Esperáos..."), las conclusionès prematuras ("Muy bien..."), las preguntas y respuestas que el poeta o el niño se hace a sí mismo, las exhortaciones a mujeres indefinidas. La memoria de la ninez se entrelaza con la memoria del amor (15) y precisamente la respiración oprimida del niño acongojado por el misterio o por el sentimiento de culpa (cf. Tr. III o Tr. $L I)$ coincide en este poema con las solicitaciones sucesivas de la fiebre. Lo mismo en los poemas del amor que en los poemas de la niñez, un solo recurso queda a la congoja del poeta: el universo de las cosas familiares, y simultáneamente los movimientos del lenguaje en perpetua

número 6, del cual no hay manera de evadirse; por otra parte "te hablo" del segunda verso trae consigo la palabra "dialecto", substituída a la palabra que podíamos esperar : "paredes", el adjetivo : "entero", subraya lo definitivo y total de la sensación.

(14) En la imagen : "y siquiera podrán /servirte mis nos musgos y arrecidos....", tenemos como la etapa intermedia entre un procedimiento de origen modernista ("Cruzan dé boca en boca los ingenuos buen día, /como hilo de alegre rocío cntre las rosas...." - Herrera y Reissig : Buen Día) y la existencia independiente del algunos vocablos abstractos en los poemas más dificilmente desentrañables de Trilce.

(r5) Para el nombre "Tilia", recuérdese Ascuas en Los Hcraldos Negros. 
zozobra dejan presentir desde un principio que el bienestar en esa forma alcanzando es fundamentalmente culpable e inútil.

En Trilce LXXIV (16) podemos apreciar nuevamente la conexión entre el lenguaje poético y la incapacidad radical del poeta para evadirse de su condición dolorosa; el último verso: "Para que te compongas" confirma esa misma condición con un rasgo de impotente ironía que termina con el poema sin concluirlo verdaderamente.

Existe asimismo cierta similitud de atmósfera entre poemas como Tr. XXIII y XXVIII y por ejemplo Triice XXXV (17) donde "los encantos de la mesa" resultan espiritualizados por la presencia de la mujer amada (la cual explica también expresiones como: "esta núbil campaña"). Una vez conjurados los peligros del impresionismo por esa constante confrontación del plano humano con el de las cosas ("sus palabras tiernas/ como lancinantes lechugas recién cortadas" : imagen sin mayor originalidad formal pero con virtud propia de resonancia vallejiana), apenas es necesario indicar todavía la permanencia de la expresión hablada (palabras o giros : "suelta el mirlo... y nos marchamos ahora sí..."), la falsa conclusión ("Pero hase visto!"), la intensidad inmediata de la sensación, la cual a veces queda fijada en una sonoridad que no abandona hasta haberla agotado por completo (" $a$ la orilla de una costura, a coserme el costado a su costado" - cf. en el poema anteriormente comentado: "máquinas cosedoras dentro del costado izquierdo").

"Mujer, que sin pensar en noda más allá... en los pocos momentos felices que sustrae as lo desconocido a partirs de una sensación actual, sin prolongación trascendente (cf. Tr. XVI: "Tengo fe en ser fuerte...": fe que surge en un momento de bienestar amoroso), el amor presenta los mismos caracteres que el hogar materno revelado por Vallejo. La fidelidad a una emoción física, que conforta al igual que el "yantar" del niño en otros tiempos ("Nadie sabe mi merienda suculenta de unidad..."), rige, como siempre en esa poesía, la forma misma del poema.

(16) La "concretización" del tiempo en el primer verso: "Hubo un día... que ya ni sé qué hacer con él" nos recuerda un antiguo procedimiento de la época herreriana, pero adaptado a una atmósfera poética nueva (véase por ejemplo El reloj caído en cl mar de Neruda).

(17) 'Aunque al principio notamos cierta vacilación en el significada conferido a la mujer, la evocación de la comida sitúa inmediatamente el poema en la perspectiva del "ahora". En cuanto a los versos: "casi un programa hípico en viołado etc." se refieren a algo muy conocido del público limeño de la épaca: el color y el largo de los programas del hipódromo. 
En Trilce LXXI, metáforas de cuño todavía herreriano, que señalan en el punto de partida la presencia del mundo exterior ("Serpea el sol... Vánse los carros flagelados por la tarde..."), se elaboran mal que bien a lo largo de una súplica urgente del poeta ("Cállate. Nadie sabe... Cállate. No respires... etc.") y ceden a cada rato ante la evocación o mejor dicho la narración directa del acto del amor ("Tus manos y mis manos... practicando depresiones, y sienes y costados... - este celo de gallos ajisecos..."). "Regocíjate huérfano..." : el llamado final de alegría que el poeta se dirige a si mismo dentro del clima permanente de orfandad en que vive desde niño revela lo suficiente la imposibilidad de elevarse hasta un plano sentimental, y la confusión del erotismo con el instinto de todo lo bueno inmediatamente para el cuerpo, de todo lo que protege contra el abandono en las tinieblas frías, hostiles, del universo, aunque sea en forma siempre momentánea.

En Trilce XXX, el amor es totalmente afirmado en la "quemadura del segundo", y el poema amenaza con perderse en una serie de sensaciones nada estructuradas (han desaparecido los verbos) que dejan presentir como una trascendencia rudimentaria sin afianzarla ("con lo que estamos siendo sin saberlo").

"Pienso en tu sexo...":- leemos al principio de Trilce XIII, poema donde esa sensualidad, en estrecha conexión con la experiencia de la niñez, se expresa a través de símbolos triviales o de fórmulas directas que hacia el final se insertancen un crepúsculo aún modernista(18): "Oh, escándalo de miel de los crepúsculos. 1Oh, estruendo mudo". (con los colores y los sonidos superpuestos). La inversión completa del último verso: "¡Odumodneurte!" corresponde a aquella ruptura brusca de los poemas - en vez de conclusión - que en otras partes hemos visto indicada por exclamaciones irónicas o familiares, repeticiones de versos anteriores, etc.

(18) Insistiremos por última vez en la persistencia, en Trilce, de recuerdos literarios de la época madernista; los cuales, probablemente involuntarios en su aparición, no logran desarrollo coherente pero sirven a veces como punto de partida de tal o cuall composición, v. gr. Trilce $X X X I$ : "Esperanza plañe entre algadones...'; o Trilce $L X I I I:$ "...B B́en peinada la mañana chorrea el pelo fino....", En el primero de los poemas citados, el verso inicial que es recordado hacia el fin determina la atmósfera general del conjunto, pera en el detalle de los versos seguimos, a través de algunas exprésiones puramente verbales sin aparente substrato objetivo, un largo plañido, patético en su constante humildad, con exclamaciones jadeantes ("Cállate miedo...."), hasta el grito final: "Y basta" que una vez más deja el poema sin conclusión, el dolor sin otro recurso que la afirmación desesperada de la voluntad para no tenerlo en cuenta. En Trilce LXIII, toda la primera parte está constituída por elementos recibidos de la poe- 


\section{EL NUEVO LENGUAJE POETICO}

El "lenguaje descoyuntado", característico de Trilce según juicio de José Bergamín, aparece en conexión constante con la actitud fundamental del poeta que tan sólo puede intentar nombrar lo innominable en el momento de su manifestación inicial, cuando las cosas no son recibidas todavía como elementos de representación sino únicamente como amenaza o salvaguardia. Si consideramos poemas con el mismo tema intuitivo, entendiendo el tema en su más amplia definición, podemos apreciar los resultados diferentes, para no decir divergentes, en cuanto a la expresión poética, que sin embargo provienen. de la misma zozobra espiritual del escritor. Acabamos de considerar poemas donde la intuición primitiva se traduce en una forma imitada de las formas íntimas de la conversación del niño o del amante: Tr. LXII, por ejemplo, es un poema de amor; pero, en el otro extremo del registro expresivo, Tr. $V$, que estudiamos en un capítulo anterior, es también a su modo un poema inspirado en la sensación amorosa; entre ambos poemas cabe una variedad de composiciones cuya fuerza afectiva procede, alternativamente, de las conmociones verbales insólitas o de la transmisión casi infantil de la emoción.

En Trilce VI, que por un lado recuerda Idilio Muerto de Los Heraldos Negros, la nostalgia amorosa se organiza en forno a un elemento de la vida corriente, el traje, y a partir de la unión verbal inicial que resuelve con audacia sugestiva el sufrimiento experimentado en el seno mismo de las contradicciones temporales ("El traje que vestí mañana..."), se presentan los arcaismos ("mi aquella lavandera"), los neologismos con fuertes resonancias ("otilinas, fratesadas"), las expresiones con base objetiva, pero expuestas a caer en un verbalismo gratuito ("en mis falsillas encañoña el lienzo para emplumar"), mientras que los diversos momentos del poema nacen unos de otros ("no lo ha lavado... lo lavaba... y si supiera... y si supiera...") hasta la

sía modernista, aparte de los dos primeros tenemos otros versos de cuño netamente herriano : "en mal asfaltado oxidente de muebles hindúes.... rumia la majada y se subraya/ de un relincho andino...."); en la segunda parte dichos elementos se organizan conforme una determinación familiar que recuerda, desarrollándola, la última palabra de $T r$. $X X X I$ : "Pero bastan las astas.... Basta la mañana...", y también engendran expresiones típicamente vallejianas : "quietas hasta hacerse uno...." - sobre todo los dos versos finales en los cuales la espiritualización de los momentos temporales se asocia con la obsesión de los números y de los contrarios para crear como un nuevo toque fúnebre qué termina el poema : "y busca las once /y no son más que las doce deshoras". 
proyección en mayúsculas del grito, incapaz en otra forma de resolver la ausencia, el recuerdo y la inmensidad del deseo actual.

Un paso más hacia los "bordes espeluznantes" (1) y encontramos, por ejemplo, Trilce IX : las proposiciones eróticas más directas (desde "su válvula que se abre en suculenta recepción" hasta "aquel ludir mortal de sábana") están integradas en un simbolismo numérico ("sus dos hojas anchas... los dos tomos de la Obra...") que se intensifica en un esfuerzo como para dislocar el lenguaje, cargándolo con más significación de la que puede expresar. Los vocablos surgen bajo la impulsión de un poder explosivo, seco y destructor ("a treintidos cables y sus múltiples"), se forman con el poema ("enveto, se arrequintan, toroso") (2) un poema sacudido por una vibración sorda, ardiente, desde el primer verso cuya fuerza de sugestión se transforma y renueva al principio de cada estrofa: "Vusco volvvver de golpe el golpe...".

"Hay golpes en la vida...". tales eran las palabras iniciales de la obra toda de Vallejo; el verso que acabamos de citar recuerda esos golpes en la hora misma de hablar del amor $Y$, a través de la incorrección de la escritura, cuyo origen ( tan sólo el origen) podemos encontrar en la imitación del lenguaje hablado (cf. Tr. LII), la tensión recíproca de las dos palabras: "Vusco volvvver...", más expresiva por el empleo del verbo simple: "volver" en lugar del compuesto "devolver" y por la redundancia de la letra $v$, de pronto autónoma como en el abecedario de un niño (cf. Tr. XXIII) T- dicha tensión procura traducir gráficamente la voluntad furiosa, si bien en realidad impotente, de recuperar en el presente lo que una vez ha sido y todavia puede dejar de presentarse como ausente ("y no vivo entonces ausencia, /ni al tacto"). Las dos sentencias finales aparecen de nuevo como una afirmación irrefutable pero inmotivada (la confusión: "alma de la ausente, alma mía" está relacionada con ese clima de confusión temporal tan frecuente en la poesía de Vallejo).

Un recuerdo amoroso es el punto de partida de Trilce XXVI : en la primera estrofa, la incoherencia, desde un punto de vista lógico, de una metáfora ampliamente desarrollada tiende sin embargo a crear, por los elementos elegidos, una impresión única, la de un amor que está ya de luto ("echa nudo, cárdenas cintas, sollozo, orinientos, moribundas,").

(1) Fórmula de Vallejo mismo en su carta a Antenor Orrego al poco tiempo de la publicación de Trilce.

(2) ¿Qué pensar de "todo avía"? La expresión juega probablemente con "todavía" y con "avía", puesto en vez de "había"; podemos ver en este ejemplo el interés y al mismo tiempo el peligro de semejante clase de invención. 
Al concretarse el tiempo, el simbolismo de las ciudades muertas (Cuzco, Alejandría) se anuncia, en una atmósfera de sollozos y pesares, cuando de pronto ese simbolismo en proceso de organización desaparece ante la imagen erótica que se impone, sin la menor transposición, y durante las dos estrofas siguientes dirige la grafía misma de los versos :

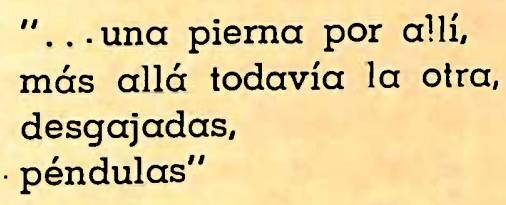

- imagen puramente física, como animal ("imás piernas los brazos que brazos!").

La cuarta estrofa define, al contrario, unas consideraciones generales, presentadas como conclusión: "Así... Y así..." (3) y termina en una interrogación inquieta : ". . con cuatros al ombro /ya para qué tristura" (el valor sugestivo del último vocablo es mucho mayor que el de "tristeza"). De la emoción en esta forma suscitada nace de repente otro recuerdo, otra sensación, más elemental que la anterior (es sensación de tacto), apenas enunciada ("las uñas aquellas...") pero insistente en su carácter doloroso hasta iniciar uno de aquellos párrafos a base de oposiciones $y$ de convergencia de contrarios que nos encaminan hacia una nueva retórica ("crecen ellos para adentro, mueren para afuera...").

"Las uñas" : a partir de la sensación que prolongada se introduce nuevamente el simbolismo (respecto a la avestruz, cf. Avestruz - L.H.N. y $T r . X X I$ ) al mismo tiempo geográfico y amoroso ("el estrecho ciego de senos aunados"), el cual termina perdiéndose en la misma atmósfera del principio, mientras conserva la obsesión de las uñas, de lo que desgarra y también la presencia latente del amor ("Al calor de una punta... etc.").

Tal vez más que en otros poemas, podemos observar el paso diferente de cada estrofa, que proviene de instancias sucesivas, recibidas por el poeta e imprevisibles para el lector (el poema no adelanta, no progresa hacia un final determinado como hacen los poemas

(3) Adviértase al mismo tiempo la adjetivación nueva, (de la cual el mismo Vallejo formula el principio en $T r$. XXXVIII : "Los sustantivos que se adjetivan de brindarse...."); como en ejemplos anteriores, marca la humanización dulce y humilde de codas las cosas: "luz eternamente polla... dedos hospicios....". 
simbolistas), pero simultáneamente el nexo afectivo sostiene la composición y une entre si, aunque no las lleva a una conclusión, las distintas partes del poema.

Si en vez de considerar los poemas con inspiración erótica, hubiéramos estudiado aquellos en donde persiste, entre otros elementos, la imagen de la niñez, de la madre y del pan, (4) preponderante en $T r$. $L X V \circ$ en Tr. XXIII, hubiéramos encontrado idéntica variedad de poemas que va desde la evocación inmediata con expresionismo emotivo hasta los trozos en donde la renovación completa del lenguaje usual se vuelve necesaria para tratar de remediar las insuficiencias del mismo.

Entre Trilce XXXIX y Trilce LVI (5) notamos ya una diferencia sensible; la angustia del segundo poema citado se expresa por bruscas negaciones ilógicas en el seno de la afirmación ("y tomo el desayuno sin probar ni gota de él") y por la tensión hasta el límite ("hasta dónde esto es lo menos... y nos quisieron hasta hacernos daño...") característica de muchos otros poemas de Trilce. En Tr. LXVII p. ej. tenemos dos versos que dicen: "...Si vendrá aquel espejo/que de tan esperado ya pasa de cristal...": recordemos inmediatamente Tr. XXXVIII donde la imagen dominante del pan, de todo aquello que se come, termina imponiéndose a la materia aparentemente más contradictoria - el vidrio - pues la identidad de cada cosa o de cada ser no resiste la proyección del deseo en un tiempo todavía por venir ("Este cristal es pan no venido todavía "), hasta ceder al empuje de imágenesabstractas que proba. blemente indican la única liberación posible (liberación de los límites del lenguaje, condición de la liberación de cualquier otro límite: "Y márchase ahora a formar las izquierdas/ los nuevos Menos").

La niñez está presente igualmente en Trilce XLVII; los primeros versos se apoyan en una superposición de sensaciones y de nociones: visión borrada de las islas costeñas del Perú, a través de las pestañas que tienden a juntarse y con los párpados medio cerrados, - persistencia de una emoción infantil, casi ancestral, a través de las referencias histó-

(4) En algunos poemas como Tr. $L X V I I$ podríamos seguir al mismo tiempo ambas presencias: lal amante y la madre.

(5) En el primero de los dos poemas tenemos otra vez como punto de partida una sensación indeterminada e inquietante (cf. $T r . I$ ) y luego damos con la falsa conclusión : "Pero, eso sí....", después de las confesiones de impotencia : "Qué me importa.... Qué se va hacer...", con un tono de ternura adolorida: "Ni ese bueno del Sol... me esperaría....". La declaración con la cual se inicia $T r$. LVI retumba en la obra toda de Vallejo: "Todos los días amanezco a ciegas a trabajar para vivár...."; el elemento exterior, la sensación, quizás determinante del poema, aparece aquí al final como respuesta y posibilidad: "Fósforo y fósforo...". 
ricas. El recuerdo de la niñez se vuelve progresivamente más puro hacia el final, visión y al mismo tiempo pérdida de la visión: "Se va el altar...", pérdida sin remedio ni remisión que tampoco aquí concluye : "Y las manitas... Y siendo ya la l" (la implacabilidad del tiempo, de la hora lleva el poeta a renunciar a las letras y a aceptar los guarismos en la grafía poética). En el curso del poema, en verso como: "Ciliado archipiélago, te desislas a fondo...", el neologismo procede asimismo de aquella obsesión de los contrarios que vemos chocarse, llamarse o destruirse de un modo a veces más, a veces menos sugestivo.

Retablo en Los Heraldos Negros, constituía como un "arte poético" de la primera manera de Vallejo, todarvía mal desprendida de la atmós fera modernista. En Trilce también descubrimos, al menos en dos oportunidades, por parte del poeta, unas declaraciones de principios, que confirman todo lo que podemos decir del libro.

En las líneas iniciales de Trilce $L V$, la oposición : "Samain diría... Vallejo dice..." es categórica (Samain representa la poesía simbolista, la de la época anterior), (6) y el poema inmediatamente se convierte en prosa, al menos en el segundo párrafo que evoca algunos trozos de Escalas Melografiadas. Siguiendo una voluntad de autodefinición, las palabras-claves sel reunen, creando obsesión $C^{\prime \prime} .$. hoy la Muerte está soldando cada lindero a cada hebra de cabello perdido... el miércoles con uñas destrozadas, etc..."), mientras los elementos de la realidad exterior (una enfermería o un hospital) se van precisando poco a poco ("versos antisépticos... uñas de alcánfor, etc..."), para luego perderse nuevamente en la persistencia irremediable de las imágenes febriles ("allá... enfrente"). El poeta se salva únicamente por la ironía afectuosa, sin amargura y los pretextos ilusorios de una falsa lógi-

(6) Samain figura siempre en los recuerdos de los "bohemios" de Trujillo cono uno de los poetas más leídos por todo el grupo de amigos entre los cuales Vallejo se inició a la poesía. La cita de Samaini es de la segunda estrofa del poema Automne, en cl libro : Au Jardin de l'Infante, la que dice así :

"Comme dans un préau d'hospice ou de prison

L'air est calme et d'une tristesse contenue,

Et chaque feuille d'or tombe, l'heure venuc,

Ainsi qu'un souvenir, lente, sur le gazon".

Es posible que el poema de Vallejo haya sido inspirado por la enfermería de la cárcel trujillana, cuya reallidad vivida y desgarradora era por supuesto muy diferente de la realidad soñada por Samain de un patio de hospicio o de cárcel, agradablemente triste y nostálgico: 
ca tranquilizante (cf. en Tr. XII : "¿Qué dice ahora Newton? /Pero, naturalmente, vosotros sois hijos...").

No hay poema en el cual las condiciones profundas de todo el libro resulten mejor expresadas que en Triice XXXVI : aquel sufrimiento elemental que tropieza constantemente con los límites de lo posible y de una realidad inexplicable no tiene traducción más eficiente, en un lenguaje que asimismo intenta trascender los límites. La primera palabra "Pugnamos...", indica claramente esa tensión para libertarse de cuanto contraría la vida, el "forajido tormento" (Tr. LIV) largamente experimentado en los poemas de la niñez y del amor: la figura 'evangélica ("ensartarnos por un ojo de aguja"), la paradoja matemática ("el cuarto ángulo del círculo"), (7) la continuidad establecida entre los sexos ("hembra se continúa el macho") (8) son otras tantas manifestaciones del deseo de emancipación en camino de realizarse (adviértase la progresión:" (1) Pugnamos ensartarnos... (2) Amoniácase casi... (3) Hembra se continúa. ." ).

La segunda estrofa, (como en otros poemas cada estrofa presenta una unidad particular que no procede del desarrollo continuo de la estrofa anterior, sin dejar nunca de contribuir a la significación general del poema) - la segunda estrofa queda fijada en una imagen característica: la Venus de Milo, imagen recibida fuera de las normas tradicionales de la perfección clásica (tal como la consideraran las estéticas de los siglos pasados), en la "'perenne imperfección" de su brazo mutilado, el cual, "increado" mejor que "cercenado", pugna a su vez por buscar una forma que presiente sin lograrla - símboblo del poema y trata igualmente de escapar a la determinación de la piedra, en una frase cuya forma misma, dura, recargada, apremiante, traduce la violencia de una lucha inútil.

Las expresiones que entonces se acumulan tienen diferentes orígenes; los "verdeantes guijarros gagos" (9) se enlazan directamente con la presencia de la estatua; "ortivos", adjetivo raro pero cuya resonancia (indica todo lo que nace o pretende nacer) explica la aparición,

(7) En Los Caynas (Escalas Melografiadas), el loco Urquizo realiza "el triángulo de dos ángulos" entre otras infracciones a los sacrosantos principios lógicos (cf. $\operatorname{Tr}$. $X X I X$ : "Pasa una paralela a ingrata línea quebrada de felicidad...").

(8) Nótese en el verso siguiente: "....y precisamente a raíz de cuanto no florece...."; tal "prosismo sintáctico" (Amado Alonso en su comentario a la poesía de Nerucia) está relacionado en Vallejo con el procedimiento tantas veces apuntado de las falsas conclusiones (cf. el estudio posterior sobre Poemas IIumanos).

(9) "Gagos" : utilización por Vallejo de un vocablo anticuado para expresar la ironia dolorosa propia del momento. 
trae probablemente por una similitud auditiva: "nautilos", y de pronto vienen las palabras del vocabulario temporal tan importante en esa poesía: "Vísperas inmortales (cf. Enereida - L.H.N.)... aunes que gatean...". Hay que deternerse en la última expresión citada: los límites entre las diferentes categorías de palabras no existían para Vallejo y los adverbios especialmente podían ejercer sobre su mente la misma fuerza persuasiva que cualquier otro vocablo; los repetía como ya dijimos, hasta agotar su contenido y tanto en su hablar diario como en sus obras poéticas los adverbios de tiempo han desarrollado siempre, conjuntamente con los números, un papel predilecto (véase p. ej.: $T r . X L$ : "trasdoseadas de dobles todavías"); dichos adverbios existen, pues, fuera de las categorías gramaticales y pueden substantivarse ("aunes que gatean") como dar origen a nuevos verbos ("existencia que todaviiza" (10) - cf. Tr. VII : "trasmañanar las salvas en los dobles"). Las violencias impuestas al lenguaje son la consecuencia $o$ el corolario de la tentativa para escapar de todos los obstáculos; cf. Tr. LIV : "a vaces doyme contra todas las contras".

La orden expresa que inicia la tercera estrofa indica netamente el nuevo principio poético, en ruptura, como si fuera necesario recordarlo, con todas las tentaciones de la poesía anterior: la Venus de Milo, símbolo de ârmonía para los clásicos y todavía para los simbolistas ya acaba de ser considerada según otras perspectivas; ahora tenemos la declaración en forma terminante. "Rehusad la simetría a buen seguro...". Después de esa generalización progresiva, el vocablo "tal", como primer elemento de la éstrofa siguiente-indica solamente el retorno a una sensación tan absurda como irrefutable ("siento ahora al meñique/demás en la siniestra"); y todo el esfuerzo de liberación viene a fracasar en la imposibilidad de hacer que lo que es deje de ser: "y no hay cómo salir de él". Nunca hay cómo salir de lo que es; la pirueta que termina la estrofa, jugando de nuevo con las contradicciones del tiempo, no hace sino acentuar los límites de la realidad. En la disposición misma del grito final se manifiesta una ambigüedad dolorosa : el poema recae sobre la palabra "orfandad" que continuamente asoma en la obra de Vallejo desde Bajo los Alamos, el texto sin embargo menos personal y más cargado de influencias de Los Heraldos Negros, pero en el cual el tiempo ya se ha convertido en el signo de la desnudez del hombre y de su ignorancia.

(ro) "Aún, todavia" son adverbios del tiempo en movimiento; expresan las realaciones privilegiadas de lo continuo y de lo transitorio, de lo perenne y de lo frágil de la experiencia temporal. 
Un poema como Trilce XXVII que no ofrece ninguna dificultad gra. matical, ninguna novedad lingüística vuelve a encontrar en forma completamente natural el ritmo hablado de las composiciones de la niñez como Tr. III o LI. Está construído a base de reiteraciones con valor emotivo: "Me da miedo... No entremos. Me da miedo...", y de la superposición de la imagen actual: "ese chorro", de la imagen pasada: "triste esqueleto cantor" y de la palabra misma: "recuerdo", individualizada, como personalizada - con la derrota siempre sensible : "Me da miedo este favor /de tornar por minutos, por puentes volados". El vocabulario de la impotencia reaparece : "El chorro que no sabe a cómo vamos...", y la sensación persiste, inquietante: "silba, silba". Los versos, cuchicheados, acuden, con extraña discreción y complicidades familiares, camunicando el escalofrío de la angustia que serían incapaces de enunciar explícitamente (cf. en Tr. VII los encabalgamientos significativos : "...por la veteada calle /que yo me sé. Todo sin novedad /de veras..."). Las "tomas... a la realidad" (¿la tentación impresionista?) no presentan nunca ese aspecto de sequedad que la expresión completa, "tomas a la seca realidad", parece anunciar; ya hemos recalcado lo suficiente el hecho de que las interferencias objetivas en los poemas son aceptadas en primer lugar por el impacto efectivo que determinan : dolor, y más raras veces consuelo.

Ocurre también que el poeta se vuelve más decididamente hacia sí mismo en una exploración de los abismosinteriores (cf. Tr. VII : "Y fondeé hacia cosas así, / y fui pasado...") : con Trilce XXXIII, una de las composiciones más acabadas del libro, y de vocabulario principalmente abstracto, tenemos el poeta del retiro del mundo exterior y como un remontarse hasta el tiempo que precede el nacimiento. Relacionado con la sensación, o mejor dicho la ausencia de sensación, de la lluvia (en Los Heraldos Negros, la lluvia significaba siempre renuncia e intuición de la muerte), vemos por una vez formularse el voto o el deseo (11) de establecerse en un más allá anterior a la angustia, en un momento en que ésta no existe todavía pues el ser que padece de ella tampoco ha empezado a existir.

A partir de la expresión del deseo inicial, el poema es compuesto, como tantos otros, a la vista del lector: el poeta lo recita al mismo tiempo que lo escribe de corrección en corrección ("... de aquí a mil años. Mejor a cien años no más..."), con palabras que se hacen esperar hasta el verso siguiente (... a puro /pulso..."), otras que reapare-

(Ix) Es un voto, un deseo más bien que una voluntad: cf. en L.H.N. expresiones como: "Hay ganas de .... etc.". 
cen ("la fibra védica, la lana védica...") o insisten ("mi fin final..."). El hablar poético sigue la línea indecisa de la intuición, mientras la imagen de la madre y de la amada alteran paulatinamente la esperanza que quería surgir del paso primitivo de la renuncia, hasta confundir lo que fué y lo que podría ser en una misma fatalidad dolorosa. Las dos últimas estrofas nacen con esa seguridad (el tiempo de los verbos cambia) y se contentan con repetir en distintas formas el toque, entonces definitivo, del fracaso y de la imposibilidad de librarse del tiempo: "no alcanzaré a librarme...".

En Trilce LIX, idéntica seguridad adquiere un giro vertiginoso de expresión, el dolor se agiganta a la escala del mundo, sobre un fondo objetivo, inmóvil e inhumano ("Pacífico. Andes..."). "Acaso. Acaso... y se afila, /y se afila... vuelta /y vuelta..." : el poema mismo termina desintegrándose en ese remolino inevitable que procuraba traducir y en la última estrofa tenemos versos en los cuales la palabra ele-

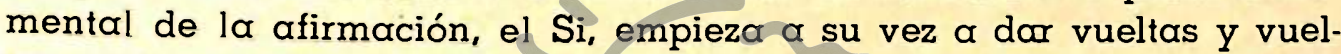
tas, primero con momentos de pausa, y luego en forma acelerada hasta que estalla en su contrario, un "NO" mayúsculo gritado en el supremo sobresalto:

\section{"Centrífuga que sí, que sí, que Sí,$$
\text { quẻsíoque sí que sícqūe sí: No !" }
$$

A través de los "dos' âtimos trozos considerados, sensiblemento diferentes entre sí, vemos el poema resolverse igualmente en la reiteración obstinada de lo inevitable, con todas las salidas cerradas por las afirmaciones que se acumulan por el agotamiento de una sola palabra, signo inmediato de cuanto forma obstáculo al deseo del hombre. En una forma un poco más elaborada (con el correctivo de la estrofa fi$\mathrm{nal}$ : "Y se apolilla mi paciencia..."), la proposición que inicia Trilce $L X$ : "Es de madera mi paciencia, sorda, vegetal..." (12) expresa, la tonalidad general de todos aquellos poemas que nunca están completamente formulados, como un testimonio de las "inminencias" del lenguaje ("cf. Tr. XXXVI : "Laceadora de inminencias, laceadora /del paréntesis...") cercado por los límites de lo existente.

En $T r . L X$ un principio de elevación con antecedentes en Enereida: ("Día que has sido puro..."), los recuerdos modernistas evidentes (las

(12) En Sabor, Neruda cscribirá: "...Quićn puede jactarsc de paciencia más sólida?....". 
"américas inéditas" tienen que ver con las "américas ocultas" de Dario y "el domingo bocón del sepulcro" es una metáfora de carácter herreriano) y la oposición final bastante retórica ("esta horrible sutura del placer que... etc.") no impiden sin embargo un último grito más personal: "...que nos DestieRRa!", con una disposición gráfica que acentúa la palabra definitiva, la cual oímos retumbar, dura, "sorda, vegetal", al mismo tiempo que la percibimos con la vista.

La angustia infantii, siempre a punto de asomar en los versos, con sus incertidumbres, su pudor, su insistencia, su ternura y también sus alegrías ocultas (podríamos seguirla nuevamente en Tr. XLIII : "Quién sabe se va a tí...") es constantemente acechada, renovada por las sensaciones dolorosas del presente que se vuelven enloquecedoras $y$ permanecen inexplicables. El objeto que determina la sensación puede inclusive "interiorizarse" e invadir al ser por completo: véase por ejemplo Trilce XLIV, "Este piano viaja para adentro...", donde las inversiones violentas y voluntarias ("con tu sordera que me oye, /con tu mudez que me asorda...") no son suficientes para absolver la pesadilla. En otra página del libro - Trilce LXVI - el sentimiento directamente inspirado por la impresión primitiva: "Dobla el dos de noviembre..." subsiste por detrás de las intuiciones intermedias ("Vosotros difuntcs de las nítidas rodillas...") y reaparece al final, tal vez más apremiante, para instalarse en las nuevas sensaciones exteriores: "Y la rama del presentimiento lse la muerdeun carto ques simplemente /rueda por la calle".

\section{"Jorge Puccinelli Converso"}

El choque de contrastes (y la subsiguiente explotación inédita de los recursos del lenguaje) surge entonces de la tentación de encontrar una salida, en Trilce LXIX por ejempio de la visión infinita y obscuramente ejemplar del océano (" oh mar con tus volúmenes docentes..."), visión progresivamente más inquietante ("...saltas... saltas, hachando, hachando...") y que termina maltratando el vocabulario (falta un adjetivo que signifique: en forma de labios y aparece "labiados"; el vocablo raro, científico, se impone con valor desconcertante, preciso y sugestivo: "quelonias"; las letras mismas crean imágenes: "estáticas eles") - visión que finalmente el poeta puede definir tan sólo por una nueva cabriola inesperada: "El mar, y una edición en pie..." (la palabra de coordinación es evidentemente ajena al desarrollo interno del poema); luego, a partir de la última expresión se origina una tentativa absurda y decisiva para agotarlo, para destruirlo todo, de la cual no sabemos si multiplica la angustia o si le abre una solución: "en su única hoja el anverso /de cara al reverso...". 
El primer movimiento de Trilce $X L V$ es directamente opuesto al del poema anterior : "Me desvinculo del mar..." y parece a punto de realizarse uno de aquellos breves momentos de comunión dichosa que la mañuna a veces inspira (Cf. Enereida): "Oh prodigiosa doncellez..." (véase igualmente Tr. XIX : "Penetra en la maría ecuménica..."). Pero el misterio de lo profundo (de las cosas y del hombre : "husmeo los tuétanos...") no deja ni un instante de invadir las sensaciones presentes ("teclas de resaca....") y la última estrofa es típicamente ambivalente : la posibilidad o mejor dicho la seguridad de tropezar a cada paso con el absurdo ("Y si así diéramos las narices (en el absurdo....") es aceptada y casi reivindicada. Lo absurdo mismo realizado ("nos cubriremos con el oro de no tener nada, etc.") parece ofrecer una solución y el imperio de lo que nace, de lo que va a adquirir la categoría de ser ("el ala aún no nacida"; cf. el brazo increado de la Venus de Milo en Tr. XXXVI, en Tr. LXXVII, "la costa aún sin mar" y en Tr. XL la bella expresión: "hueras yemas lunesentes") (13) o de lo que pierde su ser a fuerza de serlo ("... ala que a fuerza de ser una ya no es al $\alpha^{\prime \prime}$ ) excepcionalmente encamina el poema hacia la realización.

En otra oportunidad - Trilce LXXVII - la posibilidad de lo absurdo es simultáneamente temida como inminente y llamada en función emancipadora: la sensación de lluvia actual intenta multiplicarse $y$ persistir, ("No se vaya a secar esta lluvia") liberadora de una obscura sequeadad (podríamos decir? sequía) interior, por lo que trata de eludir todas las leyes físicase: P'mojadol en el agua dque surtiera de todos los fuegos". "Agua... fuego..."; las palabras que ordinariamente se excluyen aquí se buscan y encuentran (14) en inversiones patéticas : "¿No subimos acaso para abajo?" - (cf. Tr. LXVIII : "Y llueve más de abajo ay para arriba..." - Tr. LXX : ". . escaleras, escaladas, en horizontizante frustración de pies..."). En Trilce XIV una expresión paralela: "Esas posaderas sentadas para arriba..." parece nacer al contrario de una sensación (de circo), tan inexplicable (15) e inevitable como los modos de ser ordinarios; lo absurdo se ha realizado: "Eso no puede ser, sido. /Absurdo. "El final del poema es característico : la afirmación repentina de otra certidumbre, también inevitable pero de ín-

(13) Los dos adjetivos se destruyen mútuamentc y el segundo, creado ex profeso, significa nacimiento, el paso del domingo al lunes.

(14) C.f. en Tr. XIX esos pares de contrarios que se niegan mútuamente y acumulan los efectos : "....masticando hielo, /mastiquemos brasas, ya no hay donde bajar, /ya no hay donde subir....".

(15) Adviértase el primer verso del poema: "Cual mi explicación". 
dole familiar, biográfica nos ofrece un ejemplo más de esas conclusiones que no concluyen nada:

"Pero he venido de Trujillo a Lima.

Pero gano un sueldo de cinco soles".

Con frecuencia el poema, acosado, ciego como la vida (Tr. LIII : "Cabezazo brutal"), crispado en la traducción de una sensación hostil (véase el principio de $\operatorname{Tr} . X L$ ), busca una saljda siempre negada (Tr. $X L$ : "Como si nos hubiesen dejado salir! Como /si no estuviésemos embrazados siempre /a los dos flancos diarios de la fatalidad!"). $y$ el sufrimiento se instala en todos los rincones (Tr. LIII : "Veis lo que tenemos que aguantar, /mal que nos pese..." - Tr. XX : Mas sufro. Allende sufro. Aquende sufro..."). El hombre arrastrado en los "círculos viciosos" del tiempo (Tr. XXI), empieza a despertar a la vida consciente, todavia tributario de su animalidad ( $T$ r. $X X$ : "Y he aquí se me cae la baba... (16) - Tr. LXVIII : "blanqueó nuestra pureza de animales..." Bulla de botones de bragueta.. El desaguie jurídico..."). (17) y, para forzar los límites, las fronteras tan invariables como innumerables (Tr. LIII : "La frontera, la ambulante batuta..."), no puede sino atacar las determinaciones del espacio y del tiempo y realizar en palabras lo objetivamente imposible (Tr. LIII : "IcIs dos piedras que no alcanzan a ocupar /una misma posada a un mismo tiempo...").

Hemos señalado en páginas onteriores que la obsesión aritmética está estrechamente vinculada ton semejante posición vital y estética. En Tr. $X$ el principio de dicha conexión se encuentra terminantemente ấirmado:

"Cómo detrás desahucian juntas

de contrarios. Cómo siempre asoma el guarismo

bajo la línea de todo avatar...".

Los números aparecen en los poemas, escritos en cifras tanto como en letras. Trilce $X X X I I$ es un poema significativo de la utilización gráfica ("999 calorías..." - cf. Tr. LXXVI : "tan sólo estuvo a 99 burbujas ...") o verbal ("Treinta y tres trillones trescientos treinta y tres calo. rías..." - cf. la palabra misma : Trilce) de los números siempre temi-

(16) Ya hemos encontrado en otros poemas la misma ironía burlona cue domina en estos versas, como recurso de la ternura contra la ignorancia $y$ el misterio.

$\left(x_{7}\right)$ Es frecuentemente en la poesia de Vallejo la permanencia de "emociones" puramente físicas de esa clase: cf. Tr. $I$ y $T r . X I X$ que hemos comentado anteriormente. La inminencia de la muerte en Poemas IItmanos laará más frectzente aún las refe. rencias a estas realidades. 
bles en el misterio de su ser. En realidad, la subordinación demasiado directa a una sensación de calor, insoportable, sofocante (los ruidos que la acompañan son imitados en los versos, igualmente obsesivos: "Rumbbb... etc.") (18) - sensación de la cuai se escapan tan sólo unas aspiraciones apenas elaboradas ("Quién como los hielos. Pero no... - Mejor no digo nada...") hacen del poema que consideramos una experiencia aceptable por las condiciones elementales que nos revela, pero difícil de repetir so pena de alienar por completo iel principio mismo de la poesía.

El poema que verdaderamente expresa la obsesión de los números de los cuales ignoramos cómo pasan de uno a otro (cf.Tr. XX : "pues apenas acerco/ el l al l para no caer...") (19) es Trilce XLVIII: como punto de partida tenemos una advertencia trivial ("tengo ahora 70 soles peruanos..."). la cual inicia todo el mecanismo de la alucinación ("mis tímpanos alucinados") - ritmo ("... la que suena... - llameante, llameante...") y palabras ("arde llameante... espejea ... forcejeando... chisporroteantes... gritttos...") - hasta terminar en una generalización llena de amenazas:

"acaba por ser todos los guarismos, la vida entera".

Desde entonces el amor está contemplado en el secreto del "dos" (Tr. XVII : "Destílase estè 2 en cuna sola tanda. S" - Tr. LXXVI : "En nombre de esa pura que sabía mirar hasta ser 2 ...") y a cada instante surgen como realidades incomprensibles pero ineluctables - signo ejemplar y privilegiado de cuanto es sin poder ser negado - aquellos conjuntos numéricos de los cuales hablamos corrientemente sin preocuparnos por lo que contienen de inexplicable: las dos manos ( las manos siempre separadas que el poeta quisiera reunir con un puente Tr. LIII, - lo mismo que desearía establecer otro puente entre hoy $\mathrm{y}$ ayer o mañana: Tr. LXXVI : "dos días que no se juntan..."); los 360 grados del círculo ( $T r$. LIII); las 12 horas del día (Tr. XXX) que se oponen en negaciones irreductibles (Tr. LIII : "Quién clama las once no

(18) En la tercera estrofa unas imágenes principiantes, derivadas de un modernismo familiar, no presentan mayor originalidad, si no es por el mismo humorismo de siempre.

(19) El conocimiento del misterio del número sería el conocimiento ejemplar que permitiria elevarnos por encima de la angustia de la existencia : C.f. $\operatorname{Tr}$. XLIX : "quicro reconocer siquicra al $\mathrm{I}$, /quiero el punto de apoyo, quiero /saber de estar słquiera....". 
son doce..."); los 7 días de la semana (Tr. LXVIII); los días del mes (Tr. XXI : "Diciembre con sus 31 pieles rotas..." - Tr XVII : Junio... en tus 21 uñas de estación..."); los 12 meses (Tr. XXI : "Diciembre ... el magro señor Doce..." - Tr. $X$ : "Se remolca diez meses hacia la decena... Dos quedan por lo menos todavía en pañales...", y con la intervención del recuerdo amoroso : "Y los tres meses de ausencia./ $Y$ los nueve de gestación.").

La preeminencia de las nociones temporales en ia enumeración anterior indica sin equívoco posible la prioridad de la experiencia perso nal del tiempo, un "tiempo de deshora" raras veces favorable (Tr. XVI: "Al aire, fray pasado..."): dicha experiencia, ya sensible en Los Heraldos Negros, se apoya en las sensaciones inmediatas y generales (cf. en Tr. LXVIII, la "tarde" y la "lluvia": abandono y bienestar con amenazas imprecisas) y se incorpora naturalmente en la insurrección de los contrarios, de las fronteras y de los guarismos (cf. nuevamente Tr. LXVIII : "desde qué hora el bordón, al ser portado, /sustenta y no es sustentado...") que finalmente tropieza con lo irreductible de la visión exterior (en la conclusión de Tr. LXVIII : "Y era negro, colgado en un rincón, /sin proferir ni jota, mi paletó...", las letras del abecedario terminan escapándose, cada und formando un verso, hasta detenerse en la evidencia de una mayúscula ya aislada de toda palabra : " $\alpha / \mathrm{t} / \mathrm{o} / \mathrm{d} / \mathrm{a} / \mathrm{s} / \mathrm{t} / \mathrm{A}$ ".

En el presente todo estó experimentacto como presencia, como falta o como aspiración; el "ahora" abarca todas las emociones y todas las pérdidas de la vída y la deficiencia fundamental del poeta no le permite elevarse por encima de las indicaciones actuales.

Hay poemas donde la experiencia del "ahora" nos es relatada lisa y llanamente con frases que se dilatan hasta abandonar la forma misma de la versificación (como anunciando los poemas en prosa que los editores de Poemas Humanos han reunido al final del último libro). Al principio de Trilce LXVI advertimos cierta contracción del lenguaje: "Hitos vagorosos enamoran, desde el minuto/montuoso..." (cf. Tr. LVII : "Craterizados los puntos más altos, los puntos /del amor..."); en esta superposición de imágenes abstractas y de una emoción inmediatamente enunciada, lo decisivo es el sentimiento horrible de todo lo incógnito del universo; de ahí las asociaciones retóricas - independientes de los objetos y de los seres - que, en pos de la "calva Unidad", intentan conjurar, acercándolas, las dimensiones espaciales y temporales: "...hablo con vosotras, mitades, bases, cúspides... pasos que suben, pasos que baja-/n... Hoy. Mañana. Ayer.... Los poemas constantemente apoyan en declaraciones patéticas $\circ$ se detienen en la 
comprobación angustiosa pero sin remedio de lo que existe, y asimismo de lo que el poeta es sin lograr cambiarlo : "Y yo que pervivo, y yo que sé plantarme..." (cf. Tr. LVII : "...Y sobre todo el ser así... Y el éste y el aquél") - comprobación agotadora y cotidiana, apenas alterada por el grito final entre paréntesis : ("No, hombre!").

Sólo queda lugar para un quejido - un "ay" paradójicamente inciviciualizado y transformado en signo de triunfo en Tr. LXXIII ("Ha triunfado otro ay..."), poema donde el absurdo es deliberadamente reivinàicado: "Absurdo, sólo tu eres puro..." - un "ay" que más a menudo traduce una aflicción infinita. Como último ejemplo tomaremos Trilce $L X X$ : en esta pieza la angustia parece sosegarse en el bienestar momentáneo, extendiéndose la ternura heredada de la infancia hasta involucrar las piedras (cf. Las piedras - L.H.N. y el principio de Tr. $X$ y Tr. $X X$ ); el "yo no sé" pierde su virulencia a través del prosaismo irónico ("Francamente yo no sé..."), mientras que la aceptación del humilde goce presente origina las fórmulas: "Amémonos los vivos a los vivos, que a las buenas cosas/muertas será después... A m e $m \circ s$ las actualidades..."; sin embargo, a pesar de esa victoria aparente de la paz y del amor, la corporeidad misma del sosiego alcanzado ("celular de comer bien y bien beber...") lleva la amenaza de destrucción $y$, de pronto, el poema tropieza, el vocabulario se crispa con la sensación ("El porteo va en el alfar a pico...") y no subsiste sino un nuevo testimonio de impötencia. "äY temblamos avanzar el paso...".

\section{"Jorge Puccinelliconverso"}

Los poemas de Trilce fluctuan entre dos extremos, representados v. gr. por Trilce $X X V$ y Trilce $L X X V$.

Trilce $X X V$ viene a ser como el caso límite de organización que pueden alcanzar los poemas en los cuales la tensión verbal, a partir de una base objetiva mal precisada, representa el papel preponderante. Ya descle la primera palabra, que la segunda refuerza únicamente por su anclogía verbal y visual: "Alfan alfiles...", algo se encabrita en el poema, algo que duele y agarra al hombre por todos lados en el curso de la enumeración siguiente, la cual mezcla representaciones corporales precisas (junturas, testuces) con la obsesión vallejiana de las honduras y de los números.

En el verso 4, los elementos objetivos empiezan a presentarse: "Alfiles y cadillos de lupinas parvas..." ( las 4 últimas palabras si bien no tienen entre sí una relación del todo clara, están unidas por un nexo latente de significación); de origen doble (visión de la costa 
por un lado y por ołro, según parece, visión de la sierra fría), a partir de ese momento, van entreverados sin mayor preocupación por la conexión lógica: "Al rebufar el socaire de cada caravela... soberbios lomos resoplan..."; por una parte tenemos el mar, las islas guaneras, y por otra la labranza, un hombre que lleva sus animales y ruidosamente ("tiplisonancia") se suena, con la nariz helada ("carámbanos"), en medio de la intemperie. Al mismo tiempo todos esos elementos se cargan de emoción ("estevas en espasmo de infortunio... carámbanos de lástima infinita..."), provocan unos encuentros violentos, como que rechinan, entre palabras que hasta la fecha no tenían en común sino el hecho de existir simultáneamente, o se forman en el momento mismo, inauditas pero también necesarias e imperiosas ("se ennazala" está creado a base de "nasal", y en la expresión "caravela deshilada sin a-. meracanizar", (20) el recuerdo histórico colombino incluído en "caravela" determina el verbo "ameracanizar" (descubrir una América).

De referente un vocablo de valor lógico: Tal... indica como un arranque nuevo hacia una posible elucidación (la posición solitaria de la palabra "fe", separada del adjetivo "pobre" que le corresponde, subraya mientras tanto las resonancias del conjunto), pero al repetirse no hace sino entregar el poema a la irrupción de palabras libres no sólo del uso ordinario, sino de las formas mismas del vocabulario : "Cuando innámina grifalda relata sólo/fallidas callandas cruzadas" (podemos señalar sin embargo entre las palabrās de esos dos versos ciertos principios de cohesión: "innámina parece formado sobre "exámine"; "grifalda" evoca el "grifo. "grifalto", pieza antigua de artillería; por el sentido, "fallidas" lleva consigo "callandas", y las "fallidas... cruzadas" proceden de los primeros versos de la 2da. estrofa donde se hablaba de las "caravelas sin americanizar", símbolo de fracaso). Después de lo cual, para terminar, se reproduce la afirmación inicial ("alfan alfiles"), apoyada esta vez en una tercera serie de elementos intuitivos, aquellos mismos que el poeta tiene en torno suyo mientras escribe. A lo largo del poema, Vailejo no ha dejado de bordear las fronteras después de las cuales nin. guna poesía queda concebible; y el lector se deja impresionar por la atmósfera general de la obra (algo fracasado y sin acabar, subrayado en el último verso por los términos : "puertas falsas" y "borradores"), mientras no puede menos de rebelarse contra algunas expresiones que caen en todos los peligros del verbalismo.

En Trilce LXXV vendrían más bien a concluir aquellos poe-

(20) IEs probable que "ameracanizar" sea error de imprenta y que convenga leer : "americanizar". 
mas $y$ fragmentos de poemas en que la zozobra interna se expresa por medio del vaivén inquieto e insistente de un monólogo sin respues. ta, en la noche donde se afirman todas las fronteras y simultáneamen. te se confunden todos los límites que abruman al hombre. Desde el principio del poema el período gramatical adquiere una amplitud oratoria que no volverá a aparecer sino en las últimas producciones de Vallejo, quince años después. El fondo intuitivo también se desarrolla, más dilatado y deliberado, para escudriñar el misterio de la vida; los choques de palabras de sentido contrario se exaltan en la contradicción esencial de la vida y de la muerte que los intensifica a modo de una obsesión definitiva. Al principio el poeta se encuentra frente a los muertos: desde la época de Los Heraldos Negros él tiene conciencia de morir continuamente en cada día de su vida, y ya ha tenido varias o. portunidades de dirigirse en su obra a muertos precisos - su hermano Miguel, su madre - mudos para siempre, pero en cierta manera siempre vivos también ya que se les puede hablar ( $A$ mi hermaro $M i$. guel : "Oye, hermano..." - Tr. 23 ; "...tu silenciar..."); en ningún momento Vallejo se las ha con una idea cualquiera de la muerte, sino con unos seres muertos y que subsisten en una forma definida (véase asimismo el cuento de Escalas Melografiadas : "Más allá de la vida y de la muerte"); ahora bien, en el poema que estamos estudiando, estos seres empiezan a surgir de todas partes, pues los vivos igualmente están muertos : "Estais muertos..."

De un extremo alotro el poema se mantiene en esta línea precaria que descubre los dos lados opuestos de la misma manera de ser; y a partir de la primera observación, aquella trastornadora ambigüedad se desenvuelve en forma lenta y que podríamos decir voluntariamente prosaica, subrayando con los lazos lógicos puestos en evidencia todos los movimientos de un cavilar aparentemente consciente y elucidado, cuando en realidad no es sino una efusión de angustia excesiva que busca más y más palabras para explicarse ("Mientras la onda va, la onda viene...") o se limita a un quejido sin esperanza ("Triste destino.. Orfandad de orfandades") de donde surgirá a la larga el tono "bíblico" de Poemas Humanos. Desde entonces la estructura sintáctica, fuertemente recalcada, indica los saltos bruscos y vanos de la intuición, presa de un modo de razonar desesperado, en vez de poder conciliar las contradicciones irrevocables: "Quienquiera diría... Pero en verdad... Flotáis nadamente... (21) Os digo, pues, que... Quienquiera diría que ... Pero en verdad... Y sin embargo...".

(2r) La creación de "nadamente", sobre la forma ordinaria de los adverbios de miodo, acentúa más todavia la impresión de prosaismo. 
Al final, la frase : "Ellos murieron siempre de vida" parece reunir en un solo acto de intuición todos aquellos movimientos que se niegan los unos a los otros; pero lo hace tan sólo para instalar la muerte en el corazón mismo de la vida : el equilibrio entre la vida y la muerte se deshace $y$ el poema inclina definitivamente del lado de la muerte, la cual en adelante está presente en todos los momentos de la vida (cf. Agape en Los Heraldos Negros). Para concluir la repetición del "Estáis muertos" inicial cierra el poema y al mismo tiempo indica los límites extremos de lo que uno puede decir : no queda más que el silencio de la angustia irresoluta.

\section{CONCLUSIONES}

En su prólogo para la segunda edición de Trilce, José Bergamín hablaba del chileno Pablo Neruda, comparándolo con Vallejo (recordemos que en la época de Trilce, Neruda, doce años más joven que Vallejo, no había reunido todavía los poemas de la primera Residencia en la Tierra); hoy en día Vallejo y Neruda siguen siendo los dos poetas ibero-americanos, con fama nacida en la década 1920-1930, que más desconciertan a los lectores peninsulares : ambos tienen en común un lenguaje renuente a las normas y a la cohesión lógica del lenguaje literario ordinario, ( $a$ l présentar $a$ Nerudaeñ la-Universidad de Madrid, en época anterior a la Guerra Civil, Federico García Lorca, podía referírse a "bloques a punto de hundirse, poemas sostenidos sobre el abismo por un hilo de araña" (1) y asimismo "al tono descarado del gran idioma español de los americanos, tan ligado con las fuentes de nues. tros clásicos"). Pero con el tiempo, las diferencias se hacen más sensibles que las semejanzas exteriores : la "visión desintegrada" de $\mathrm{Ne}$ ruda y su experiencia de la destrucción temporal (antes de la conversión política y de la abjuración de la poesía) van acompañadas de todas las cosas, de todas las materias del mundo en perpetua descomposición en las aguas del tiempo : la poesía de Residencia en la Tierra es una poesía marcada por la presencia de los objetos, poesía compacta y sensual que, a pesar de sus audacias sintácticas, nos deja la impresión de un desarrollo denso y continuo, de una caída lenta, oscura, infinita, pero siempre llena.

(r) Adviértase el curioso paralelismo de expresión, con la autocrítica de Vallejo, cn su carta a Antenor Orrego, a raíz de la publicación de Trilce. 
En Trilce no hay universo, no hay objetos, sino los furtivamente introducidos a través del mundo escueto y familiar del hogar $y$ del amor; en general se presentan solamente sensaciones rápidas, entrevistas en un estado de semi-conciencia o de semi-vigilia, y más aún (ya que el ojo casi no tiene papel ninguno en esa poesía) recibidas como choques e indicadas por su mera resonancia dolorosa siempre sin resolver (varias composiciones empiezan así por una interrogación que no resuelven : "¿Quien?") - una resonancia interna, visceral e inclusive más profunda (Tr. 49 : "Y hasta el hueso...." - Tr. 62 : "en la confluencia del soplo y del hueso..." ). Los poemas apenas son poemas, calcados sobre el habla naciente e insistente de la niñez o de la fiebre, o más a menudo dejando que cada estrofa se organice a base de una intuición separada, pues el poeta está siempre a la merced de los asaltos repentinos de tal o cual vocablo o sentimiento de zozobra.

En Trilce tampoco hay propiamente imágenes : por cierto subsisten todavía algunas que otras metáforas de tipo modemista, último vestigio de las influencias primitivamente aceptadas, pero aquella clase nueva de imagen que tanta importancia tenía, por los años 20 , en las poéticas de vanguardia contemporáneas de Trilce no aparece en el libro. Nada tampoco ofrecido al sueño, a la evasión. La proporción de palabras abstractas en cambio es considerable. De ahí ese carácter, señalado por Bergamín, de una poesía "seca, ardorosa, como retorcida duramente por un sufrimiento animal". la cual se deshace "en un grito alegre o dolorido, casi salvaje" "Casi nunca el lenguaje domina la emoción, sino que intenta surgir simultáneamente con ella, en ráfagas que en seguida se agotan, en relámpagos tan fugitivos como fulgurantes : no parece que el poeta lo recibiera como una herencia, un legado social dado de una vez y para siempre, sino que lo creara, lo estructurara en el momento mismo, con las fallas, los fracasos, los defectos, las interrupciones, los estallidos que ello implica. Semejante propósito de asumir el lenguaje en estado naciente, no tiene, pues, parecido con el propósito nihihista de los dadaistas europeos : para Vallejo, la soledad experimentada frente al lenguaje, no es más que un aspecto de la soledad irremediable que el poeta siente frente al misterio de la vida, y cada vez que un poema se detiene, sin haber encontrado la forma adecuada para expresar tal sentimiento, lo que vuelve a surgir es la afirmación a secas, sin oropel ninguno, de un dolor inobjetable : en realidad las palabras en Trilce no logran agruparse en forma coherente, sino cuando formulan dicho lamento; el hombre no puede desprenderse de su emoción inmediata y el artista no acepta encauzar su zozobra en un molde estético, consciente y claramente asumido. 
Se han hecho interpretaciones erróneas de un juicio de Bergamín sobre Trilce, que indicaba como una de las cualidades principales de la poesía de Vallejo "su arraigo idiomático castellano". No podemos separar tal afirmación del contexto en que iba incluída : era después de señalar, entre los principios del creacionismo, el axioma de que "la poesía es esencialmente traducible" (Huidobro y Larrea escribían indiferentemente en castellano y francés), cuando Bergamín citaba para oponerla a la poesía creacionista, la poesía de Vallejo; la dificultad encontrada en traducir algunos poemas de Trilce comprueba suficientemente lo acertado de la observación: efectivamente, el hecho de que Vallejo no acepte un lenguaje completamente formado de antemano, lo ata en formo más estrecha al lenguaje particular (el castellano) que le proporciona sus materiales : un lenguaje nuevo trata de cuajar, pero a partir de este lenguaje pre-existente determinado, del cual muy bien puede dislocar $\mathrm{y}$ descomponer, o enriquecer y multiplicar los términos, sin dejar por un momento de manifestar su conexión con el mismo.

Simultóneamente, y después de abandonados los meros motivos "costumbristas", el americanismo (o mejor dicho, el andinismo) de esta poesía adquiere su significado más universal. Apenas cabe recordar que la obra de Vallejo queda estrictamente solidaria de un len. guaje hablado (2) que tolera palabras ("chirapear, aguaitar, gringo, pericote, etc.") y gires ("aquí no más, turde la noche...". también la posición casi sistemática del pronombre personal complemento después del verbo : "Ia peninsula párase. la voz rebélase, etc.") locales (con incorrecciones como"ge "en cuanto será tarde..... pugnamos ensartamos...., es más bonito de todos...") : este es un aspecto todavía elemental, pero ya revelador de la dependencia absoluta de la experiencia cotidiana. Paralelamente, la emancipación poética se inicia por la utilización de formas arcaicas, (3) o raras veces empleadas. Desde entonces, el lenguaje parece que fuera para el poeta un lengua-

(2) Io que corresponde, no a una volunat de "pinterestuismo", sino a la tentativa última de acordar el lenguaje con aquellis angustia primitiva que, como dijimor al estudiar Las flereldos Negros, si bien surge de un ambiente linguisticamente inadaptado, expresa al mismo tiempo los terrores de cualçuier hombre que se despoja por un tiempo del universo de la vida práctica o de la cultura intelectual. Resulta asinismo inaclecuado, a mejor dicho extravagante, un juicio de Xavier Abril (en el prefacio a su "Antología poética" de Vallejo) yuien eqoea al Arcipreste fe lli:a para lablblar del pexta peruano y escribe : ambos (Vallejo $y$ Juan Ruiz.) "tienen la salud y diafanidad de las aedas populares".

(3) En el aticulo Trilce (Sphinx, 1939), Carins Cueto ha podido recordar al respecto, un juicio de Juan Marinello, segín el cual, en el momentc de innovar en ma- 
je extraño, y sin embargo el único que puede utilizar para intentar la formulación del nuevo lenguaje que corresponda más exactamente a la zozobra íntima de su propio existir. El niño frecuentemente se ocupa en transformar y rehacer las palabras que los adultos le proponen, o en inventar otras nuevas; lo mismo hace el hombre para quién el lenguaje que le ofrece la sociedad, a pesar de sus muchos siglos de aparente adaptación, no constituye un medio suficientemente apropiado; "huérfano del lenguaje", él sigue siendo la criatura primitiva, reacia a los socorros ilusorios de la civilización y sin defensa contra todos los golpes que recibe desde afuera. Una experiencia sin ninguna perspectiva temporal e impropia para sociabilizarse, no acepta las formas eminentemente sociales del lenguaje sino como un recurso imposible de rechazar del todo pero nunca largo tiempo adecuado.

A partir del "yo no sé" inicial, en un esfuerzo intenso para "salir del paso" y al mismo tiempo no traicionar dicha experiencia, han surgido aquellas particularidades de la escritura de Trilce como : grafías incorrectas que imitan el hablar cotidiano (4) o más a menudo señalan una insistencia desesperada ("Vusco volvvver.... DestieRRa....); deformaciones de vocablos hasta darles vuelta completa ("Oh estruendo mudo./ Odumodneurtse!"); atracciones sonoras ("basto y vasto") que pueden llevar a neologismos ("azulinas, azulantes"); creaciones de vocablos nuevos, algunos de los cuales ("rumbar, envetar, ciliado, labiado") ison tan naturales como-los que existen en Herrera y Reissig, pero a veces encierran una fuerza indiscutible de evocación ("engirafar") " emoción ("inhumanable") SQ," en otros momentos, se hacen más audaces ("lunesente") hasta adquirir un poder sugestivo preciso e inmediato a pesar de su relación mucho más vaga con las palabras ya conocidas ("otilinas.... doneo.... fratesadas...."); conjunciones en gran parte arbitrarias del vocabulario existente ("en mis falsillas encañona el lienzo para emplumar"); explotación inaudita de las instancias corrientes de lenguaje : cambios de categoría (nombres adjetivados : "dedos hospicios..."), palabras que de ordinario se excluyen y ahora al contrario se llaman, se chocan o reconcilian como único medio para escapar de las contradicciones del lenguaje y simul-

teria de lenguaje, los americanos, prisioneros del idioma, acuden de modo natural a formas $y$ vocablos antiguamente utilizados en España; es sabido igualmente que el castellano de las regiones andinas ha conservado muchas palabras desaparecidas en regiones de la costa.

(4) Al lado de la confusión de la "b" $y$ de la "v", encontramos la confusión americana de la "s", la " $z$ " $y$ en ciertos casos la "c" : zarro, fasistol, etc. 
táneamente de la vida, - en cambio aparentes enlaces lógicos ("Y.... Pero....") que no traducen más que la incapacidad de adaptar finalmente la expresión a lo oscuro e inquieto de lo expresado (el último verso de Tr. 31 : "Y basta!" es característico del modo como terminan, sin concluir, la mayor parte de las composiciones del libro).

El lenguaje "dislocado", al igual que el lenguaje que calca las confidencias de los niños (Tr. $2-\operatorname{Tr} .51$ ), no encuentra salida alguna ni solución : los poemas abortan, comprobando la imposibilidad de librarse de las obsesiones mal definidas que ya encontrábamos en Los Heraldos Negros y se resumen en algo impersonal y doloroso siempre a punto de asomar en las páginas de Vallejo :

\section{"Veis lo que es sin poder ser negado, veis lo que tenemos que aguantar, mal que nos pese".}

Es evidente, entonces, que la poesía corre varios riesgos contradictorios : a fuerza de permanecer fiel a lo inmediatamente experimentado, puede perderse en el seno del presente $(T r .32 \circ 30)$ o en un ver. balismo no exento de arbitrariedad (Tr. 25); - por una confianza excesiva en las asociaciones de los contrarios puede permitir que se insinúe una nueva retórica, un nuevo automatismo lógico de carácter ya sospechoso en juersos como : én cuanto será tarde, temprano" (Tr. 1). En estas condiciones Trilce presenta el carácter constante de una exploración de tos límites de lo poético y nos explicamos como Vallejo, en la carta tantas veces citada a Antenor Orrego, haya confesado su miedo de que todo fuera "a morir al fondo", pues semejante perpectiva, subyacente a la obra entera, es la que le garantiza su fisonomía particular. 